\title{
Public debt and regional inequality in India: patterns, determinants, and implications
}

\author{
Sudhir Thakur ${ }^{\mathbb{B}}$
}

Accepted: 24 January 2022 / Published online: 19 February 2022

(C) The Author(s), under exclusive licence to Springer Nature B.V. 2022

\begin{abstract}
Economic recession and global health crisis have surged the public debt levels across nations to an unsustainable level. Debt can be productive provided nation-states utilize it for rapid growth and servicing the cost of loans. It can be unproductive if spent on wasteful expenditure. Thus, a relevant question is - does public debt hinder or promote growth? Reinhart and Rogoff's (American Economic Review, 100: 573-578, 2010) empirical analysis observed a non-linear relation between debt and growth in developed countries. Kaur and Mukherjee's (Reserve Bank of India, Occasional Papers, 33:1-37, 2014) analysis of the Indian economy determined a statistically significant non-linear relationship between debt and growth at state levels. Given this overview, this research examines the temporal and spatial patterns of state debt in India utilizing a statistical analysis. Geographical data are utilized to study state liability in India for 29 states and 2 union territories i.e. National Capital Territory of Delhi and Puducherry. The following three questions are addressed in this paper: (1) what is the relationship between public debt, regional inequality, and development? (2) what are the trends of public debt and regional inequality in India? (3) what are the determinants of outstanding
\end{abstract}

S. Thakur $(\bowtie)$

Department of Finance, Insurance and Real Estate, College of Business, California State University Sacramento, Sacramento, CA 95819-6088, USA

e-mail: Thakurs@csus.edu center and state liabilities in India during 1980-81 and 2019-20? Descriptive statistics (dispersion, Gini coefficient, moving averages, and Theil entropy) reveal a declining inequality during each decade as well as considerable inter-state inequality for the period. A time series regression analysis suggests lending rate, GDP growth and trade balance are negatively related to total liability at the center and state levels; net FDI flows, GDP, trade balance, and foreign exchange reserves, are positively related. Prediction maps suggest both the lagging and developed states would incur high public debts, wherein the former would utilize debt for servicing interest cost and nonplan expenditure, and the latter will utilize debt for servicing interest cost and planned expenditure.

Keywords Public debt $\cdot$ Regional inequality $\cdot$ India

\section{Introduction}

Global public debt levels have escalated to an untenable level due to economic recession and global health crisis. National debt can either be expended for productive or unproductive purposes. It can be creatively utilized if nation-states make investments for rapid growth and servicing cost of loans. It can be counterproductive if utilized for wasteful and unproductive expenditure. Thus, a relevant question is does public debt hinder or promote growth? This is a pertinent question in the wake of the recent government bailout 
of banks, and the fiscal stimulus given to businesses and citizens in developed countries. Such a trend has led the debt-to-gross domestic product ratio to surge across the developed nations. Stiglitz (2016) examined the prevailing economic stagnation and debt crisis in several pockets of the 19-member Eurozone, especially in Greece, Italy, and Spain. Such a pattern has generated questions about the 'sustainability of debt'. Similarly, Reinhart and Rogoff (2010) studied 44 nations across two centuries and discovered a non-linear relation between public debt and economic growth. They posited economic growth drops roughly by half as debt levels soars to 90 percent of gross domestic product (GDP). The former study prompted Kaur and Mukherjee (2014) to examine the relationship between public debt and economic growth at state level in India. Their empirical analysis posited a statistically significant non-linear relationship during 1980-81 and 2012-13 and observed a negative impact of public debt on economic growth. Kaur et al. (2018) subsequent study utilized the inter-temporal budget constraint and fiscal response function in a panel data framework. The analysis for the period 1980-81 to 2015-16 concluded debt levels were sustainable in the long term.

The global pandemic has had a huge impact on declining revenues and output and in increasing the cost of pandemic relief measures. It was estimated that global debt would reach 277 trillion dollars by the end of 2020 and would wreak havoc in the financial health of nations (Lu, 2020). The Covid-19 has impacted the Indian economy by supply chain disruptions and by causing mass unemployment in the informal sector. Additionally, small businesses heightened inequality across the K-shaped recovery and elevated non-performance assets in the financial sector which in turn has further constrained the fiscal space.

This overview leads to the question about the government's action plan if an economy is experiencing skyrocketing public debt. Ostry et al. (2010) exemplify three scenarios: first, if the economy experiences unsurmountable levels of debt which is a malaise for growth then a rapid reduction in indebtedness is warranted through taxes and reduction in expenditure; second, if the debt levels are moderate then the Keynesian demand management would prescribe consolidation, with an increase in public investment while interest rates are still low; and third, a middle ground would suggest if debt sustainability is not an issue then it could be reduced organically through growth and revenue management. These policy measures are contingent upon the fiscal space available to the government. Fiscal space is conceptualized as the distance between the debt-to-GDP ratio and a threshold beyond which action would need to be taken to avoid default and bankruptcy (Ostry et al., 2010).

Analogously, Martin and Pollard (2017) make the case for interpreting the role of space and place in understanding the 'constitution', 'operation', 'organization', and the role of finance, financial systems, institutions, and markets in the space economy. Christopher (2015) asserts that finance cannot be the sole domain of financial economics due to its inherent 'technical complexity'. In reality, financial decisions are made in geographical space, while money flows across urban and rural hierarchies, and promotes spatial interaction due to competition, complementarity, and intervening opportunities in places. Therefore, the spatial aspects of money and finance are important and cannot be ignored. Thus, the objective of this paper is two-fold: first, to identify and analyze the geographical patterns and determinants of public debt in India at the state level, and second, to enunciate lessons for policy-makers to curb debt level in India.

The Indian scenario: growth and debt

The Indian economy grew at a rate of 2.33 percent during the beginning of the planning era in 1951-52 and subsequently increased to 5.63 percent during 1981-82. This rate of growth declined significantly in 1991-92 to 1.43 percent due to the 'balance of payments crises. Later, the rate of growth increased impressively to 8.91 percent during 2010-11 due to the service sector boom, and in particular the growth of finance, insurance and real estate sectors. Further, this rate dropped to 5.1 percent during 2019-20 due to the global pandemic, consequent unemployment, and recession (Fig. 1). Moreover, the malaise of the declining performance has been due to the illconceived demonetization of the Modi government, poorly executed goods and service taxes, sluggish growth, and increasing levels of fiscal deficit. Chelliah (1999) has voiced his concern about the deepening fiscal crisis in India and noted that unless the fiscal deficit is reversed, it will lead to an unsustainable public debt. Also, the World Bank (2021) forecasted a contraction of the Indian economy by 9.6 percent 


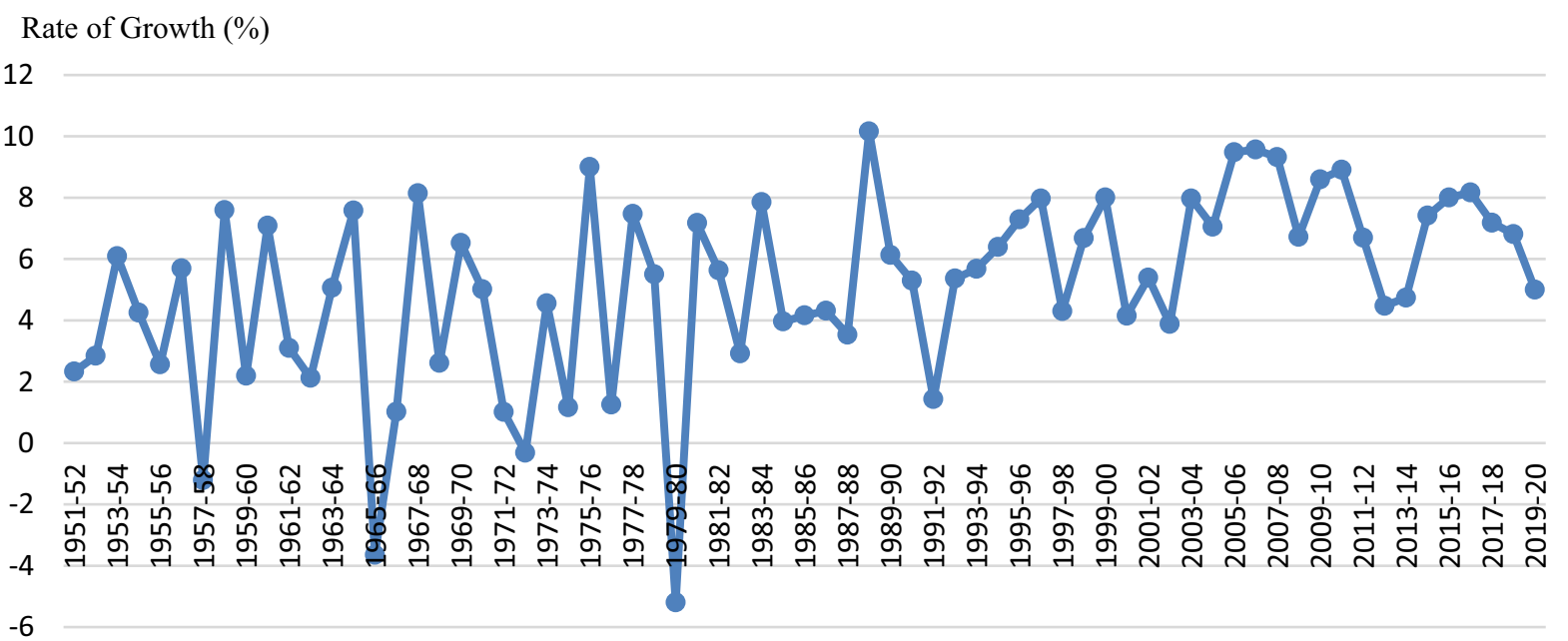

Fig. 1 Gross domestic product rate of growth for Indian economy: 1951-52 to 2019-20. Source Planning Commission, Government of India, and Economic Survey, 2018-19

in 2020-21 following recovery to 5.4 percent during the next fiscal year. This prediction is premised on a sharp decline in household saving and private investment, with the Corona virus severely impacting the informal sector which accounts for four-fifths of the total employment. This has happened at a time when the economy is falling short in performance due to non-performing assets (NPAs) in the financial sector.

Financial analysts are of the view that the Indian economy has been experiencing an exponential increase with respect to outstanding state liability to GDP ratio, from 0.03 during $1980-81$ to 0.312 in 2009-10. This ratio declined to 0.20 in $2010-11$ and has been incessantly increasing during the past decade to 0.33 in 2019-20. The outstanding state liability has been increasing persistently since 1980-81 from 26,783 to $5,258,469$ (Rupees Crores) till the end of 2019-20 fiscal year (Fig. 2). The genesis of the debt problem was due to the large and growing fiscal imbalances. Further, during the mid-1980s India faced a balance of payments problem due to the Gulf-war. This external shock led to an increase in oil import bill which was further exacerbated by exports slump, worsening of credit situation and loss of investor confidence.

Raghavan (The Hindu, 2019) observed that the center and states were moving in opposite directions with respect to debt levels. The 'Status paper on Government Debt' for 2017-18 reported a decrease in the Center's total debt as a percentage of GDP from 47.5 percent during $2014-15$ to 46.5 percent during 2017-18. However, the total debt of states has been increasing during the same period to 24 percent and is estimated to grow higher during subsequent fiscal years. This leads to the question of sustainability of debt. Policy-makers have two options. First, Indian planners can assume that the disadvantages of additional loans will outweigh the benefits from it and therefore, it can be truncated. Second, it is conceivable that in the process of attaining higher growth, additional government borrowing will be required to promote capital formation under the assumption that investments would generate a higher rate of return, and so additional capital can be raised from borrowings. Moreover, this positive rate of return can be utilized to pay service costs of borrowing and investment. Governments borrow either to meet plan expenditure-defined as expenditure on projects as roads, dams, schools, and hospitals or non-plan expenditure that include disbursement on paying salaries and interest payments.

All borrowings whether domestic, foreign, or private involve repayment obligations. First, the loan must be repaid over a certain number of years referred to as amortization payments, and second, interest payments will be paid as servicing costs until the maturity of the loan. Since the fiscal imbalance has been increasing exponentially in India during 


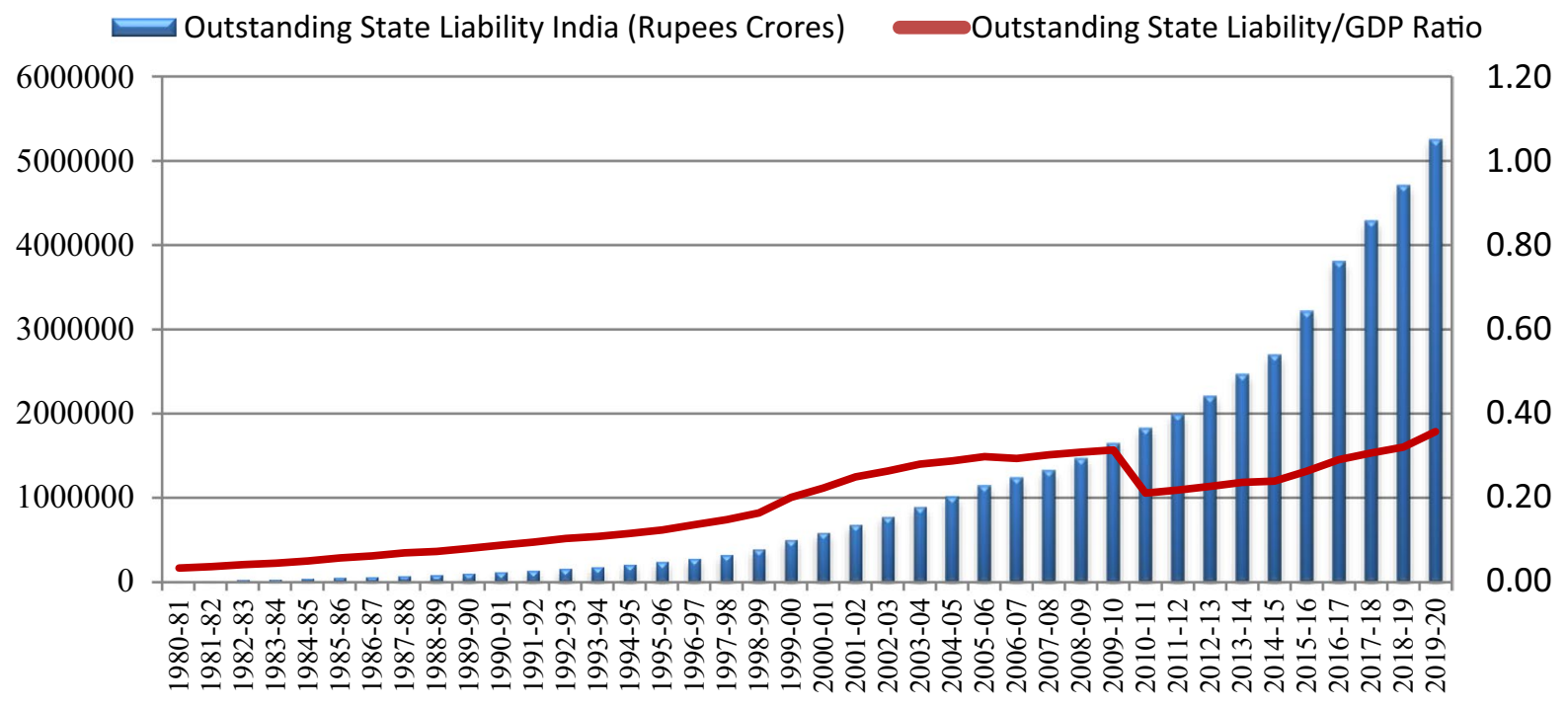

Fig. 2 Outstanding state liability (Rupees Crores) versus state liability to GDP ratio: 1980-81 to 2019-20. Source Handbook of Statistics on Indian Economy, 2008-09, 2019-20, RBI

the past decade, it would imply that cost of servicing would be rising as well. Thus, debt becomes unsustainable when it accumulates at a faster pace than the ability to pay servicing costs. This trend implies that it will discourage domestic and foreign investment, with the perception that deflation will take place and they will be taxed to service the debts deterring any further investment.

Given this overview, this study utilizes a multimethod and visualization approach to explore the geographical patterns and determinants of public debt in India. Three research questions are addressed in this paper: (1) what is the relationship between public debt, regional inequality, and development? (2) what are the trends of public debt, regional inequality in India at the state level? and (3) what are the determinants of outstanding center and state liabilities in India during 1980-81 and 2019-20? The remainder of the paper is divided into the following five sections. The second section succinctly reviews the relationship between public debt and regional development. The third section describes the research methodology. The fourth section examines descriptive statistics, visualization of debt across Indian states, interpretation of regression output, and prediction of liability at state levels. The last section concludes with implications and lessons.

\section{Public debt and regional development: unpacking the black box}

In the wake of the recent financial turmoil, the relationship between public debt and economic growth has drawn immense attention in developed and emerging market economies. Reinhart and Rogoff (2010) posits an inverse relationship between high debt and growth relationship. They classified their sample data with 44 nations into three groups with more than 90 percent debt, 60-90 percent debt, and 0-30 percent debt. In their assessment GDP growth reduces to a snail pace once government debt exceeds 90 percent of GDP (also known as a debt-burden cliff) and countries experience a spiraling downward rate of growth as debt level increases. This relationship is hypothesized to be non-linear. The debt levels are benign until a critical inflection point is reached. Subsequently, the growth rates decline as borrowing rises beyond a threshold, with subsequent tax revenue declines and spending increases. Beyond that turning point, there is an imminent danger of default and financial panic, and interest rates can rise leading to financial market stress. Moreover, the only available choices to the policy-makers will be austerity, inflation, or default. Reinhart and Rogoff's (2010) study was criticized when the analysis was replicated, since 
the study was limited by data errors, exclusion and gaps in their analysis (Herndon et al., 2014).

Economic geographers have examined this relationship from a spatial perspective. Bell et al. (2015) criticized Reinhart and Rogoff's (2010) claim of 'one size fits all' policy prescription regarding public debt and growth trade-off. They ignored the possibility that context would matter, and there can be variations in local economic structure across countries. Further, Bell et al. (2015) opined upon the importance of spatial heterogeneity and employed a multilevel modeling framework to elucidate realistically complex spatial scenarios.

It is widely understood that fiscal imbalances at the regional level are correlated with the institutional arrangements. Several researchers have addressed the issue of fiscal behavior of federal jurisdictions with subnational fiscal deficits. In particular, Molina-Parra and Martinez-Lopez (2018) examined the vertical and horizontal interaction among federal and regional governments in terms of fiscal deficit. They analyzed the Spanish regions during 1995-2010 and observed higher public deficits at the central government tier perpetuated higher deficits at the regional level. An important contribution of their research is how the process of strategic interaction among the federal government and neighboring regions influences fiscal imbalances in a federal structure. Several others have addressed the theme of strategic interaction. In particular, Baskaran (2012) examined the vertical and horizontal interaction effects of the subnational borrowing of German states during 1975-2005. The presence of horizontal interaction is evident but there is no evidence of vertical strategic interactions. In contrast, Foremny (2014) provided partial support to the premise of a positive impact from the central government deficits to the subnational deficits for the EU15 during 1995-2008. Further, Borck et al. (2015) exemplify that subnational deficit should not be ignored when there is a strong presence of strategic interaction among federations. Thus, in sum, a larger public deficit at the central government tier implies a higher deficit at the regional level and neighboring regions either in terms of geographical or ideological proximity.

Borck et al. (2015) investigated the theme of geographical spread of debt in German municipalities as a function of a neighboring municipality increase in per-capita debt. They derive a reaction of the jurisdiction's debt levels in response to their neighbor's debt levels. Next, they determine the spatial interdependence of public debt among a panel of municipalities in the two largest states of North Rhine-Westphalia (NRW) and Bavaria during 1996-2006. Analysis revealed an increase in municipality's per capital debt to the extent of 16 Euro in NRW and 33 Euro in Bavaria for a 100 Euro increase in debt per capita in neighboring municipalities. Such a trend would call for a spatial policy for curbing public debt. The debt overhang hypothesis posits a region's unmanageable debt can have a detrimental effect on economic growth via its negative effect on investor's rate of return. Moreover, Romero and Burkey (2011) examine this phenomenon in the Eurozone with an explicit focus on the spillover effects and heterogeneity that debt has on neighboring countries. They utilized a spatial Durbin model and concluded a concave relationship exists between debtto-GDP ratio and growth; and at a certain level, an inflection occurs. Their analysis postulated a turning point occurs at a lower debt-to-GDP ratio due to the spatial effects. Further, their analysis identified spatial vectors such as a strong spatial relationship between GDP growth and neighbor's GDP growth, implying when a country's growth declines it will negatively influence neighbor's growth as well. Further, Mitze and Matz (2015) explored the short and long-term relationships between regional public debt intensities and growth for German federal states between 1970 and 2010 periods. Analysis revealed a significantly negative relationship between regional public debt and per capita GDP in the long run. Statistical results show a 1 percent increase in the debt intensity reduces the long-term per capita GDP level by -0.01 percent to 0.05 percent.

Public debt in India: understanding regional variation

Public debt in India refers to the borrowings of the Central and State government. Debt can be a potent instrument for enhancing development by paying for plan and non-plan expenditure. The total debt of the state government has increased substantially from Rupees 8749 crores [ 1 crore $=10$ million] in 1971 to Rupees 27,729 crores in 1982 , to Rupees $1,58,853$ crores during 1994 and to a whooping level of Rupees $1,05,583.23$ crores in the form of loans and advances from public sector undertakings and the Central 
government as of March 31st, 2015 (Misra \& Puri, 1996; Patil, 2016).

Several studies have analyzed the relationship between public debt and growth in the Indian context and have ascertained a mixed picture. Many observed that the debt position of states are not sustainable, while others noted the declining debt to GDP ratio is attributable to improving economic performance at state levels. An optimistic observation has been noted on the fiscal health of Indian states excluding Haryana, Jharkhand, Karnataka, and Madhya Pradesh. The remainder of Indian states have shown stable state public debt as a proportion of GSDP (Makin \& Arora, 2012).

The fiscal health of Indian states during the latter part of the 1990s worsened due to several factors, namely: (1) declining central transfers due to diminishing central tax revenues, (2) pay and pension revision of employees, (3) increasing government debt and its steady accumulation harmed cost of borrowing thereby, making the state's borrowing cost soar up, and (4) coalition politics at the center and states led to a proliferation of subsidies and transfers (Rao \& Jena, 2009). In addition, Kaur and Mukherjee (2012) asserted a statistically significant non-linear relationship between public debt and growth in India. The implication of this evidence is a negative relationship between debt and growth at higher levels. The threshold level of debt to GDP ratio is 61 percent beyond which a negative relationship is observed between debt and growth. This implies debt unsustainability and calls for fiscal consolidation in the wake of potentially adverse debt dynamics. Further, Kaur et al., (2014, 2018) studied 20 states for the period 1980-81 to 2012-13 and noticed that the debt level of Indian states is sustainable in the long run. However, a disaggregated analysis suggests an overall improvement in the performance of the Indian states, although few states showed a disconcerting sign of fiscal stress and heightened debt burden. Analogously, Thakur (2020) examined public debt and growth relationship in India during 1991-2015. His analysis validated a negative relation between average debt ratio and annual rate of growth (AROG) of GDP. The regression coefficient suggests a 1 percent increase in the AROG of GDP leads the average debt ratio to decrease by 3 percent.

Bajpai and Sach's (1999) analysis of the state government finances in India suggested fiscal lacunae. They argued that while the expenditure to GDP ratio had reduced, the ratio of internal public debt to GDP has constantly increased. In addition, the debt service burden has persistently increased since interest rates have risen. Moreover, the composition of government spending has shown a lop-sided pattern towards the unproductive current expenditure, moving away from basic infrastructure provision and human resource development. They have recommended several areas for cutting expenditures at the center and state governments such as 'interest payment on domestic debt', 'fertilizer and food subsidies', 'public administration', 'grants to the states', and 'losses of public sector enterprise'. Further, a privatization approach in water and electricity departments have been suggested. This approach enunciates user charges that are aligned to the cost incurred in providing services which would attend to the goal of cutting budgetary losses. The fiscal health of Indian states have been of concern and the Eleventh Finance Commission made suggestions that led to the creation of a Fiscal Reform Facility (2000-01 to 2004-05). This facility aimed to incentivize the states to take short-term reform measures that will address improvements in revenue deficits to the extent of 25 percent. Several states like Karnataka (2002), Kerala, Tamil Nadu, and Punjab (2003) enacted legislation on fiscal responsibility and budget management. Further, this effort set a precedence that led to the enactment of the fiscal responsibility and budget management (FRBM) Act, 2003. This act manifested in proliferating the urgency of fiscal consolidation by Indian states, but did not lay a strategy for achieving a sustainable debt trajectory (Kishore \& Prasad, 2007).

Debt for all major states have increased by 66 percent during the past five years from Rupees 16,48,650 crores during 2010 to Rupees 27,33,630 crore during 2015 (Salve, 2015). The State Finance report (Reserve Bank of India, 2009) opined the level of development expenditure as a proportion of GDP increased from 9.2 percent during 2005-06 to 10.5 percent during 2007-08 and non-development expenditure declined from 5.3 to 5.1 percent during the same period. In addition, the proportion of social expenditure, which dropped during 1999-00 to 2003-04, increased subsequently from 5.1 percent of GDP to 6.3 during 2008-09 (Kapila, 2009; RBI, 2009). The RBI Report (2017) states that the introduction of an indirect tax called the goods and services tax (GST) would have economy-wide ramifications for growth, inflation, 
government finance, and external competition. This form of taxation would be a single tax based on valueaddition and would replace the myriad of local and national taxes. It will champion a new form of cooperative federalism in India based on the collaboration of the Center and States. Further, it will be the vehicle of state governments, which will manifest in a trajectory towards fiscal consolidation without squeezing productive expenditure.

\section{Research methodology}

The debt burden crisis in India has its genesis in the 1980s due to fiscal imbalances. Subsequently, the Indian economy faced balance of payments crisis. The former Finance Minister Dr. Manmohan Singh steered the Indian economy in the wake of this crisis and adopted a set of structural reforms policies: privatization, liberalization, and deregulation. Thus, the periods $1980-81$ to 2019-20 have been selected for analysis. Data from the Reserve Bank of India were utilized to collate outstanding state liability and gross state domestic product (GSDP) space-time series during the period. The outstanding state liability as a proportion of GDP (debt ratio) is examined over space-time for a deeper understanding of the evolution of debt in India (see Appendix 1). Several descriptive statistics measures such as Gini Coefficient, standard deviation, Theil entropy, moving averages, multiple regression and state lag regression models are used to estimate predicted values of state liability for the years 2020-21, 2022-23, and 2024-25. Five measures of error namely mean deviation (MD), mean absolute deviation (MAD), mean percentage error (MPE), mean absolute percentage error (MAPE), and root mean squared error (RMSE) are computed to estimate the difference between actual and predicted values for 2019-20 for moving averages and regression models.

\section{Analysis and interpretation}

This section provides a descriptive analysis of space-time trends of debt to gross state domestic product (GSDP) (referred to as debt ratio). Figure 3 shows the gross interest as a percentage of state debt in India during 2017-18. The average gross interest as a percent of state liability was approximately 7 percent (excluding NCT of Delhi).

The states of Uttar Pradesh, Maharashtra and West Bengal depict the largest share of interest payment as a proportion of state liability and the Northeastern states show the least.

Figure 4 shows the temporal pattern of average state debt ratio relative to GDP annual rate of growth during 1980-81 to 2019-20. Four episodes can be identified. The first episode (1980-81 to1996-97) shows a continuous increase in the state debt ratio. It is a paradox that in spite of high GDP annual rate of growth the average debt ratio kept increasing during the period which peaked at 0.1340 in 1996-97. Also, during the balance of payments (BOP) crisis of early 1990s the government reached a default position due to currency devaluation, current account deficit, and loss of investor confidence. The creeping GDP annual rate of growth contributed adversely to an increase in state debt ratio during the post-BOP crisis years. The implementation of structural reform measures in
Fig. 3 Gross interest payment as percentage of state liability in India: 2017-18. Source State Finances (2017-18), RBI

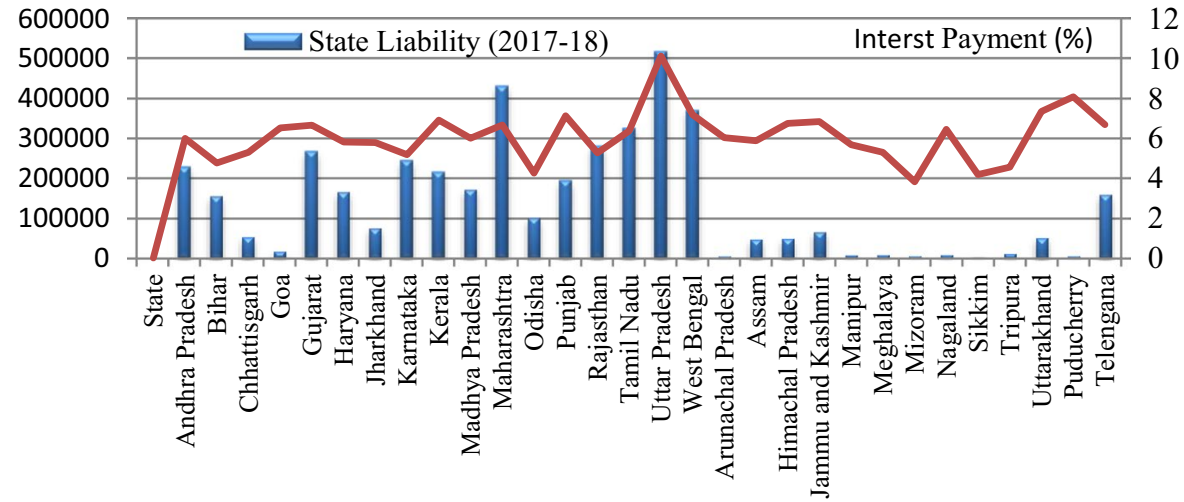




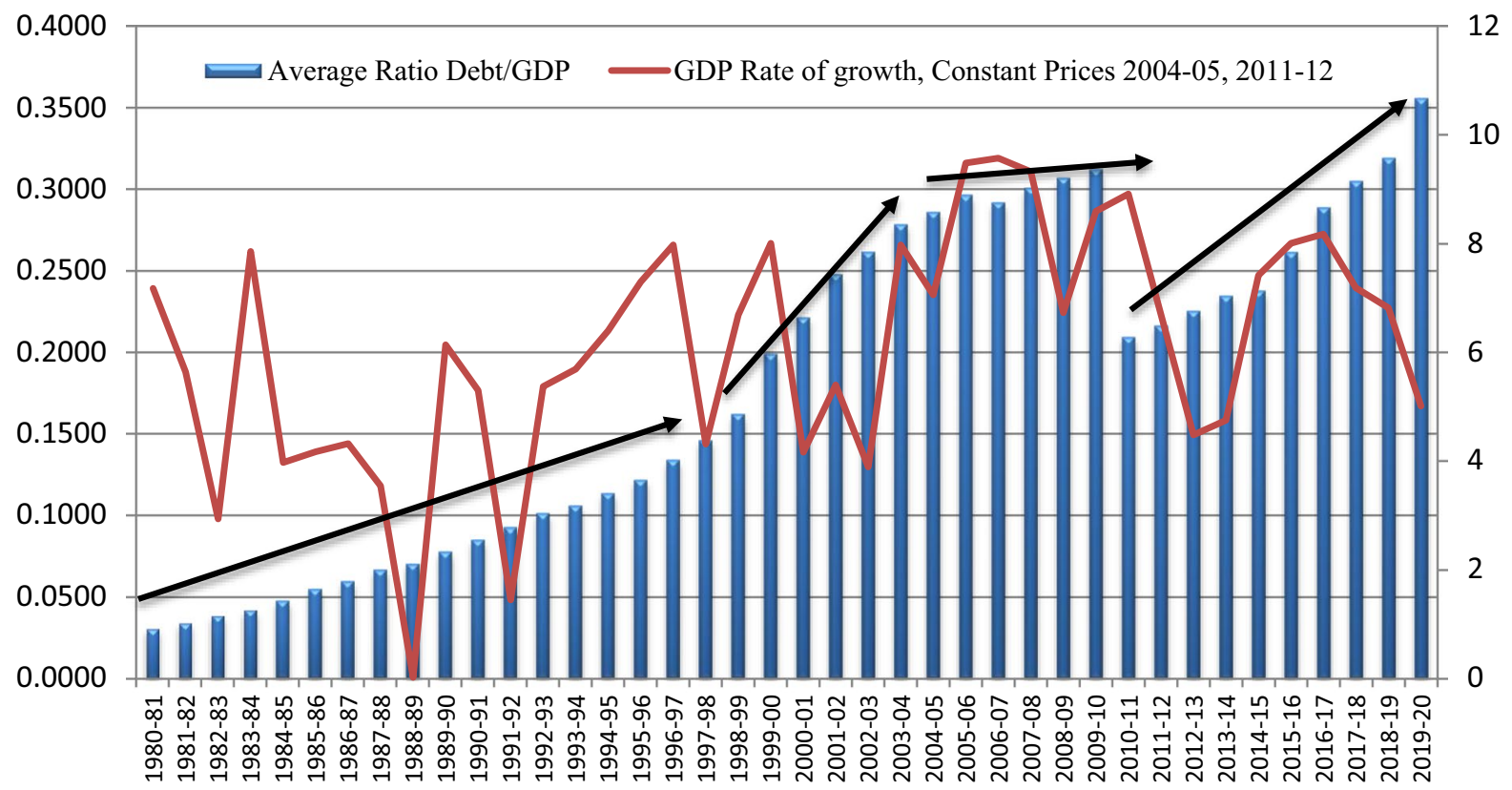

Fig. 4 Average state Debt/GDP ratio versus GDP rate growth: 1980-81 to 2019-20. Source Handbook of Statistics on Indian Economy $(2009,2020)$, RBI

the early 1990s led to the adoption of market-friendly policies and foreign investment along with liberalization, deregulation, and privatization of financial, industrial, and trade sectors. These reforms led to an improvement of the Indian economic performance.

This was followed by a second episode (1997-98 to 2003-04) of average state debt increase and a relatively slower growth in GDP annual rate of growth. The average state debt ratio peaked at 0.2786 in 2003-04. Subsequently, in the third phase (2004-05 to 2009-10) the average state debt ratio was observed to be high while the average GDP annual rate of growth was 8.45 percent during the period. During the last episode (2010-11 to 2019-20) the average state debt ratio increased sharply in the wake of slowing of GDP annual rate of growth. The reasons for an increase in the debt levels during the last decade are mismanagement of fiscal health, high unproductive expenditure, the lackluster performance of nonperforming assets, and accruing debt service burden.

However, this descriptive analysis does not provide any insight into the geographical pattern of debt in India. The six maps (Fig. 5a-f) illustrate the spatial pattern of debt ratio for selected years during 1981, 1991, 2001, 2011, 2020, and 1981-2020. The debt ratios were classified into three groups namely states that categorize within $0-44.9$ percent (low debt), 45-69.9 percent (medium debt), and 70 percent and above debt ratio (high debt). Further, an average debt ratio for forty years (1980-81 to 2019-20) were computed for delineating aggregate spatial debt patterns. For this period five classes were delineated: very low debt (0-10.1 percent), low debt (10.2-44.99 percent), medium debt (45.0-52.99 percent), high debt (53.0-69.99 percent), and very high debt (70 percent and above) for 1980-81 to 2019-20.

Figure 5a shows majority of the states in 1980-81 had debt ratio below 50 percent except for Jammu and Kashmir and Nagaland. Debt burden at state levels started to increase during subsequent decades. Three states show zero values since these states were delineated in 2000 and they are Jharkhand, Uttarakhand, and Chhattisgarh. In addition, Telangana was delimited in 2014. During 1990-91 (Fig. 5b) the high-performing states displayed a low debt ratio and these states are Maharashtra, Kerala, Puducherry and Delhi. The medium debt states comprise two clusters Rajasthan and Gujarat in the Western region and Andhra Pradesh, Tamil Nadu, and Karnataka in the southern cone. The high debt states are located in the Northeastern region, Odisha and Bihar (Eastern India) and Punjab, Jammu and Kashmir, and 


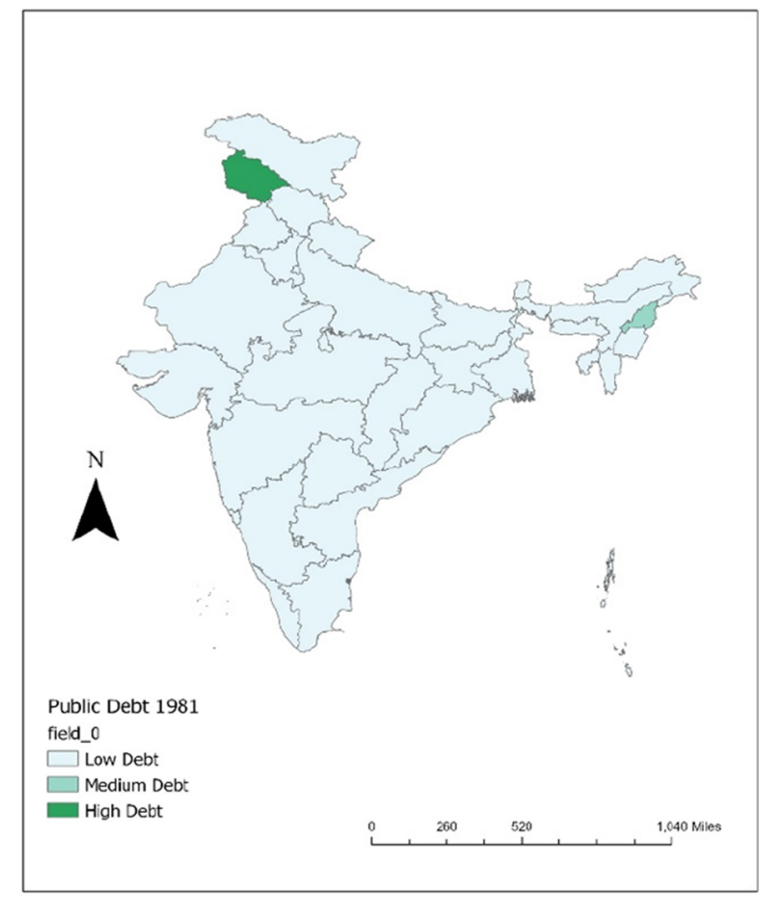

(a) Source: State Finances (1981), RBI

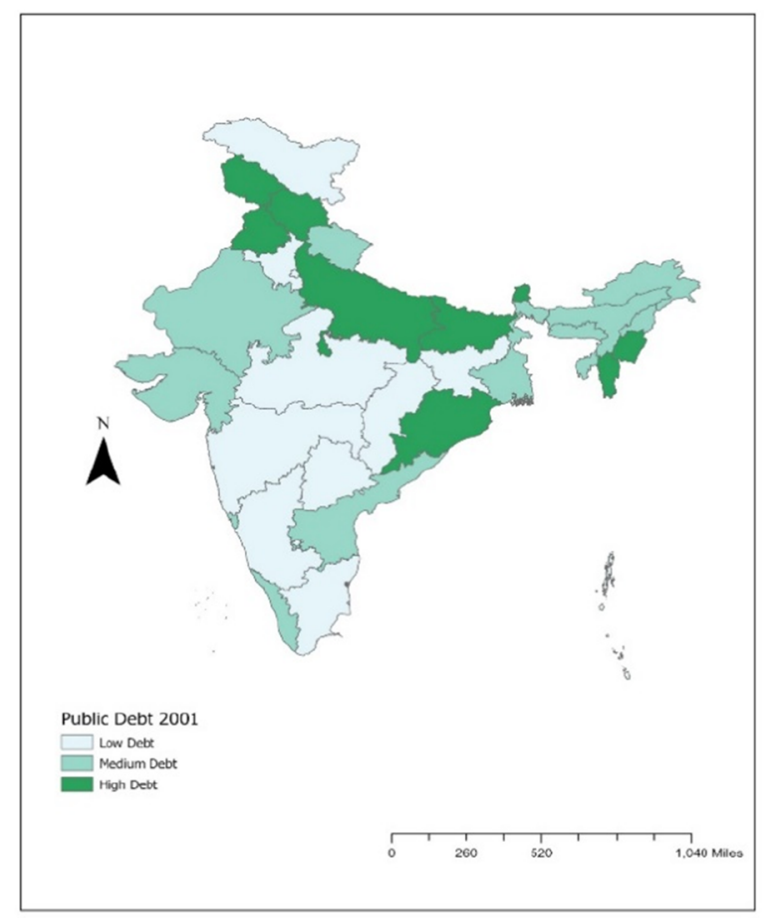

(c) Source: State Finances (2001), RBI

Fig. 5 a Debt/GSDP ratio for Indian economy: 1981. Source State Finances (1981), RBI. b Debt/GSDP ratio for Indian economy: 1991. Source State Finances (1981), RBI. c Debt/ GSDP ratio for Indian economy: 2001. Source State Finances (2001), RBI. d Debt/GSDP ratio for Indian economy: 2011.

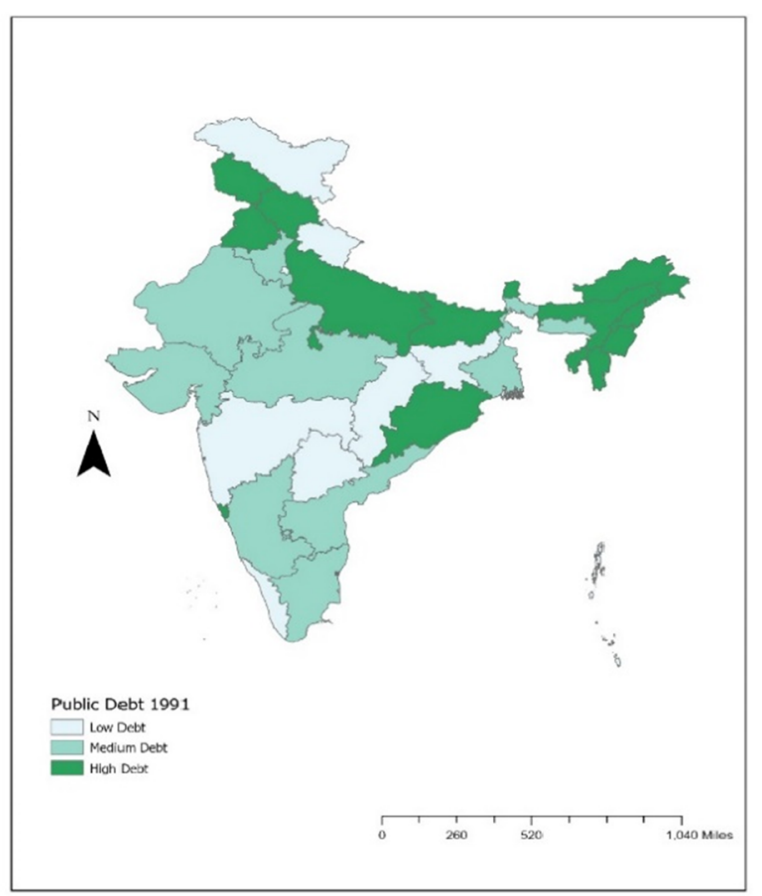

(b) Source: State Finances (1991), RBI

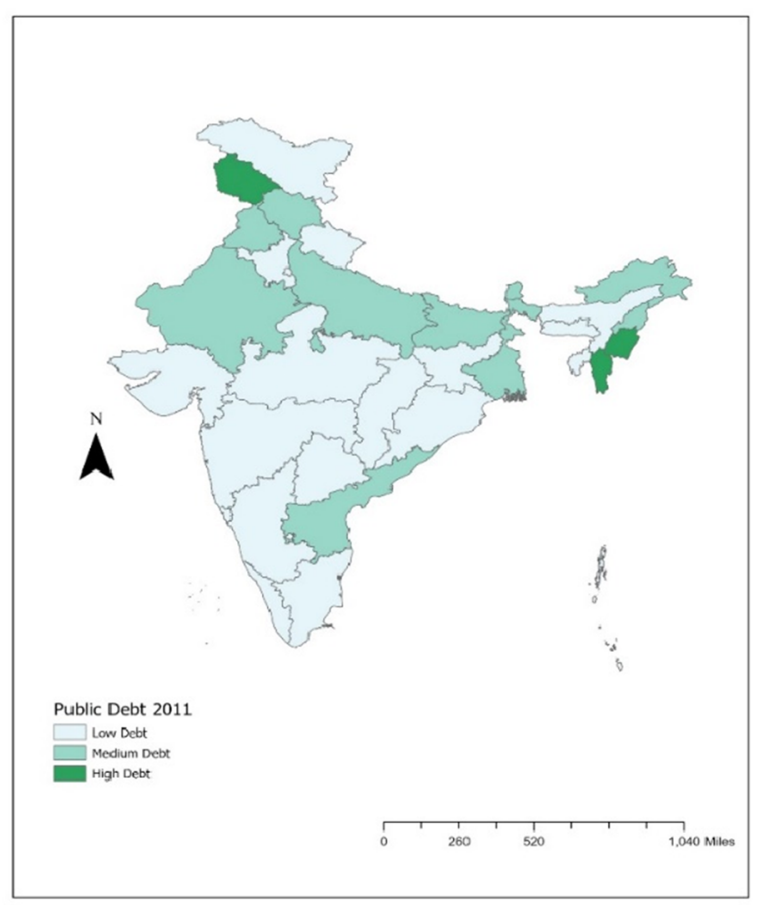

(d) Source: State Finances (2011), RBI

Source State Finances (2011), RBI. e Debt/GSDP ratio for Indian economy: 2020. Source State Finances (2020), RBI. f Average debt/GSDP ratio for Indian economy: 1981-2020. Source State Finances (Issues from 1981 to 2020), RBI 


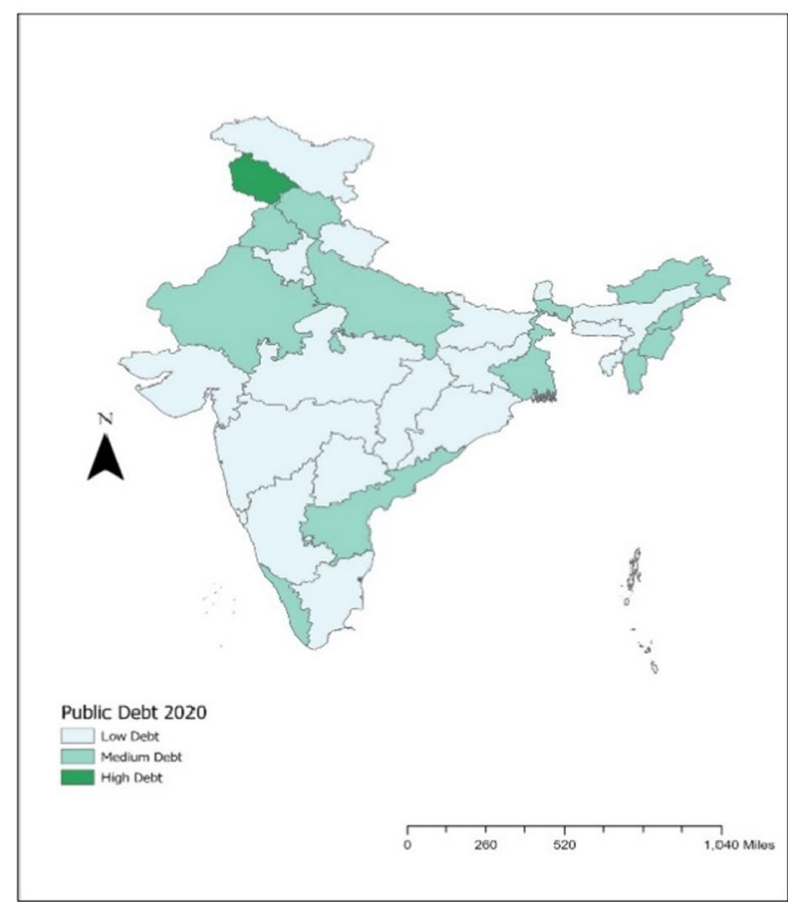

(e) Source: State Finances (2020), RBI

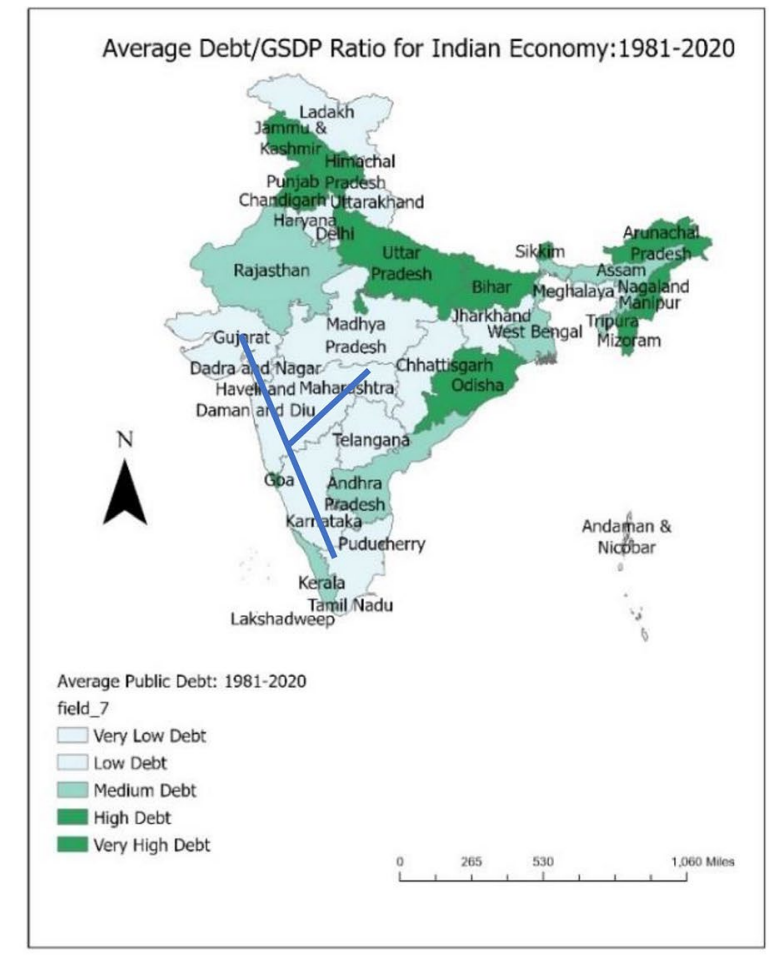

(f) Source: State Finances (Issues from 1981 to 2020), RBI

Fig. 5 (continued)

Himachal Pradesh in North India. The Northeastern states and Jammu and Kashmir are protected states under special treaties and a geographical political economy approach would better explain the uneven development in such states vis-à-vis the rest of the country.

Similarly, Fig. 5c for 2000-01 shows low debt ratio states in Western and southern India, namely Maharashtra, Karnataka, Tamil Nadu, and Andhra Pradesh in the industrial and high technology regions. The medium debt states are Gujarat, Rajasthan, Kerala, and Northeastern states. This is followed by high debt ratio states located in North, Central, and Eastern India such as Jammu and Kashmir, Punjab, Uttar Pradesh, Bihar, and parts of Eastern India.

Analogously, during 2010-11 (Fig. 5d) several states displayed geographical mobility across the three debt categories. The map reveals many states reduced their size of debt ratio. The industrial states in the Northwest and West and high technology states in the South, along with Tamil Nadu, Haryana, Delhi, and Kerala were in the category of low debt states.
Medium debt states were spread out in Himachal Pradesh, West Bengal, Punjab, Bihar, Rajasthan, and several Northeastern states. The high debt ratio states are a small cluster of Mizoram, Manipur, and Jammu and Kashmir.

Subsequently, after a decade during 2019-20 (Fig. 5e) there was further shift, and only one state i.e. Jammu and Kashmir was in the category of high debt ratio. The number of high debt ratio states reduced and several transitioned to medium and low debt ratio categories. The medium debt category consists of Punjab, Rajasthan, Himachal Pradesh, West Bengal, Uttar Pradesh, Kerala, and Andhra Pradesh. The low debt ratio states comprise Bihar, Madhya Pradesh, Odisha, and other industrialized and high technology states in the western and southern regions of India. This trend can be manifested due to the effect of high growth performance and better public debt management.

The last debt ratio map shows an aggregate spatial pattern for 1980-81 to 2019-20 (Fig. 5f). Three clusters can be identified. The high debt states are located 
in Jammu and Kashmir, Bihar, Sikkim, and most of the Northeastern states. The medium debt states comprise most of the Western, Northwestern, Central, and Northeastern states in India. Moreover, the low debt states are the industrial, high technology, and agricultural states in western and southern India namely Maharashtra, Karnataka, Tamil Nadu, and Haryana, which form a horizontal (T) pattern.

The overarching question from the above description is what should policy-makers do to minimize the debt liability of Indian states? Subsidies are the instrument of fiscal policy and are analogous to negative taxes. It is allocated to various groups needing assistance such as nascent industries, targeted population, food, cooking oil, education, environment, and social sectors. Subsidies are unproductive and harbor inefficiencies if not utilized efficiently. It can produce long-term positive impacts on the economy as well as can generate distortionary effects on the economy. There are various kinds of subsidies: agricultural (farm prices, water) food security (public distribution systems), petroleum, and fertilizer. The total subsidy during 2013-14 was Rupees 3600 billion ( $\$ 60.00$ billion US \$) (Reserve Bank of India, 2014). The reduction in the size of subsidy is largely a political question and needs to be dealt with by the political party in power.

Rajan (2019) argued for placing importance on 'community' beside the role of 'market' and 'state' in the course of local and regional development. The process of globalization has marginalized millions of people around the world especially in the rural communities and working class from the industrial belts in US and Europe (The Economist, 2017). If government and policymakers could develop the community first, then people's welfare in the nation would be maximized. This is antithetical to the prescription of the World Bank and IMF who have advised governments to maximize GNP as this will maximize the welfare of the population.

India has invested in many anti-poverty and employment generation programs such as integrated rural development program (IRDP), Jawhar Yojgar Yojna, rural housing, food for work program, and Mahatma Gandhi National Rural Employment Guarantee Act (MGNREGA) 2005 amongst many others. Policymakers should consider the development of the community as the basic building block for local development. The rural communities in India and the West realize that globalization has benefitted the urban population disproportionately, the rich, and the intelligentsia class. They hold the perception that the fruits of development have not trickled down to the working class in terms of education, jobs, health care, and housing, and it has yet to be seen how the $\mathrm{K}$-shaped recovery pans out during the post-pandemic recovery period. Thus, all these programs for alleviating poverty and providing social support have to be implemented through subsidies. Instead, if a community is developed first, the need for subsidy can be eliminated in the long run.

Inequality measures: Gini coefficient and standard deviation

A Gini coefficient and standard deviation are computed to analyze spatial inequality during 1980-81 to 2019-20. These computations for average debt ratio are shown in Fig. 6a and b. A Gini coefficient is a measure of inequality where the value of 1 represents perfect inequality and a value of 0 represents perfect equality. Figure 6a shows the Gini coefficient with a maximum value of 0.44 in $2003-04$ and a minimum value of 0.19 in 2019-20. It also depicts periods of increase and decrease in inequality. First, it increased during 1988-89 to 1992-93, then decreased during the following five years 1994-95 to 1998-1999. This was followed by another episode of increase till 2003-04 and then short periods of slow increase with an overall declining trajectory during 2005-09, 2010-15, and relative decline during 2015-16 to 2019-20. Thus, the debt ratio was relatively high during early 1990 s compared to the 1980s and 2000s followed by a marginal decline during the past decade. The standard deviation shows similar patterns like the Gini coefficient across the period. The highest value was 0.44 in 2003-04 and the least was 0.12 in $2015-16$ with variations in the intermittent periods.

Figure $6 \mathrm{~b}$ depicts the Gini coefficient and standard deviation of debt levels across Indian states during 1980-81 to 2019-20. The standard deviation follows a similar pattern with a range between 0.0045 and 0.43 across the period. There are considerable interstate variations in debt ratio. The states of Nagaland, Sikkim, Tripura, Odisha (eastern region), Jammu and Kashmir, Goa, Bihar, and Himachal Pradesh depict relatively higher inter-state variations in debt ratio 
(a)

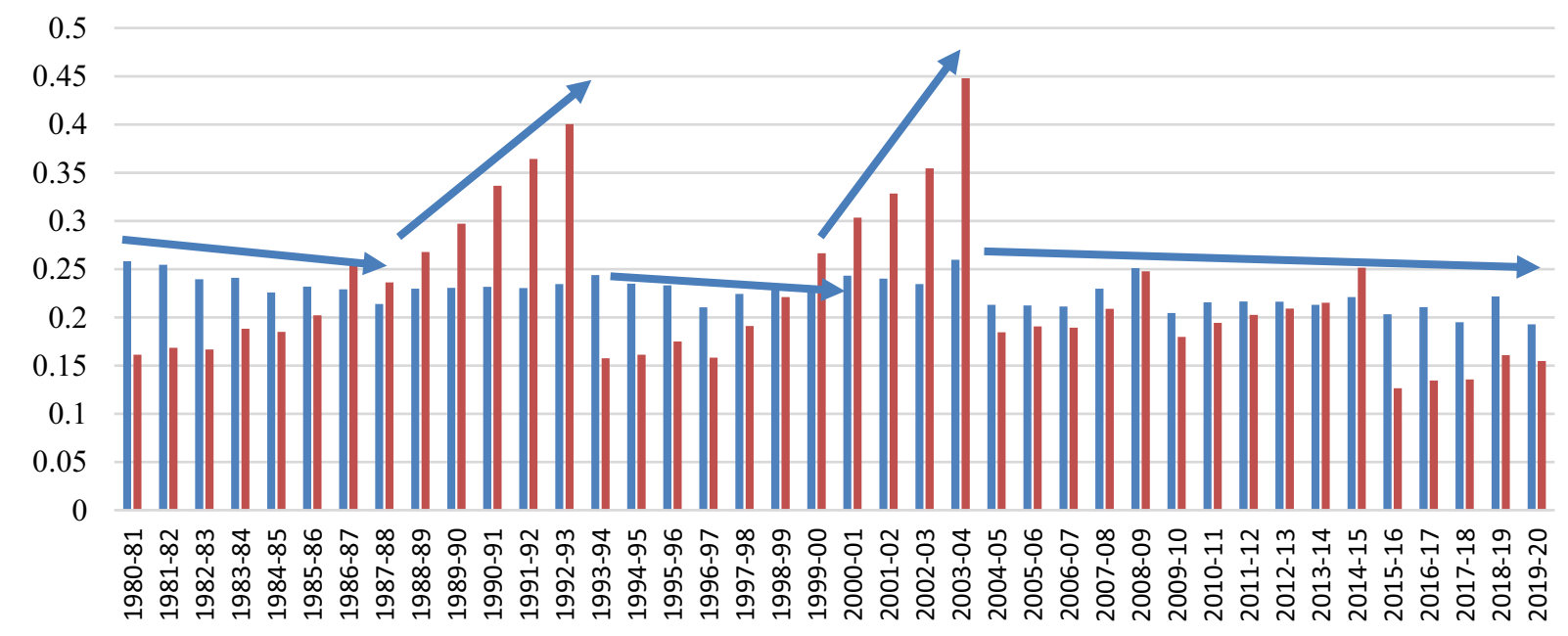

Gini Coefficient $\quad$ Standard Deviation

(b)

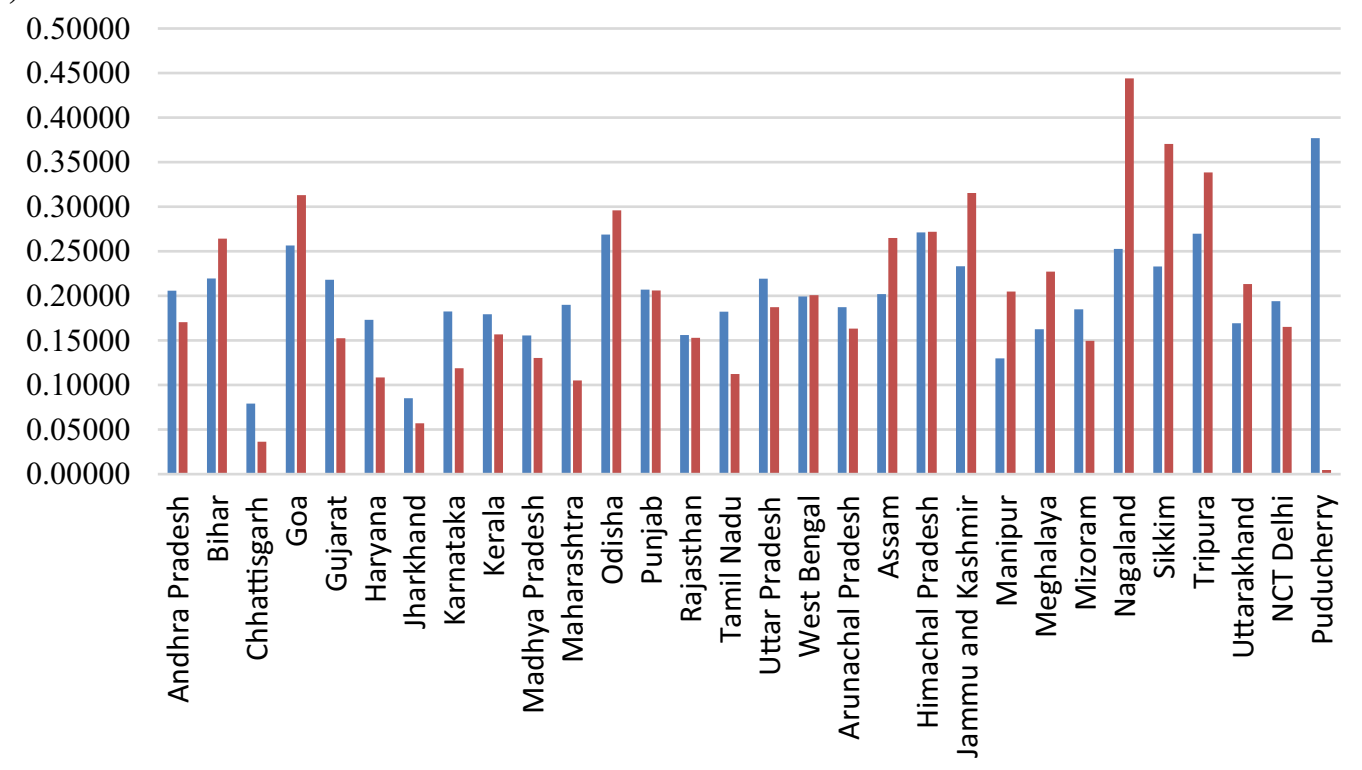

- Gini Coefficient $\quad$ Standard Deviation

Fig. 6 a and b Gini coefficient and standard deviation of state debt to GDP ratio, India: 1980-81 to 2019-20. Source State Finances (1981-2020), RBI

and the least can be observed in Tamil Nadu, Haryana, and Maharashtra. The range for the Gini coefficient is between 0.07 and 0.37 .

The highest Gini coefficient are observed in states such as Puducherry, Himachal Pradesh, Tripura, Odisha, Goa, Nagaland, and Sikkim. The least Gini coefficient is observed in Rajasthan, Madhya Pradesh, and
Manipur. Thus, there are considerable variations in debt levels across Indian states.

Theil entropy: temporal and spatial variations

Entropy is a measure of the amount of uncertainty in a probabilistic distribution or a system subject to 
constraints (Batty, 1974, 2010; Wilson, 2010). The entropy statistic has been utilized to measure temporal and spatial inequality. The entropy is defined as a statistic (Theil, 1967):

$H=-\sum p_{i} \log \left(\frac{1}{p_{i}}\right)$

where $p_{i}$ is the probability in a given region or sample (time series data). The entropy $\mathrm{H}$ measures the uncertainty of a microstate relative to the alternative microstates. If $\mathrm{H}$ is minimum and equal to zero, it implies one $p_{i}$ is equal to unity and the remainder is zero. This state implies complete certainty since there is only one microstate corresponding to a macrostate. Analogously, if $\mathrm{H}$ is at a maximum it implies that all $p_{i}$ are equal i.e. all microstates are equally likely. Thus, $\mathrm{H}$ can be utilized to evaluate either the expected entropy of distributions or the actual entropy of empirical patterns. Entropy statistic has been utilized extensively in economic geography to analyze settlement, employment distribution and population patterns. This study computes the Theil entropy of Indian debt ratio at the temporal and state levels and reports the entropy statistics (Fig. 7a, b). This measure has a range of zero to infinity. A relatively high Theil entropy indicates debt ratio is unevenly distributed across states and time. In addition, a zero entropy implies the ratio is distributed equally across the states over time.

The Pearson correlation among Theil entropy index and growth rate of GDP is (-) 0.2369 for the Indian economy during $1980-81$ to $2019-20$. This implies that the association between the rate of annual growth of GDP and Theil entropy is negative and weak. The range for Theil entropy index is 0.066-0.1297. At the temporal scale, spatial patterns cannot be observed since data is aggregated and any pattern is masked.

At the spatial scale, Puducherry shows the highest Theil entropy of 0.9102 and Haryana with the least Theil entropy of 0.0128 . In addition, the corresponding Gini coefficient is the highest for Puducherry with 0.403 and least for Chhattisgarh with a value of 0.0699 . The highest relative Theil entropy are observed for states such as Puducherry, Maharashtra, NCT Delhi, Assam and Sikkim; and least entropy in states like Kerala, Manipur, Punjab, Jammu and Kashmir, and Haryana. This implies states with higher Theil index are more persistent while the states with low Theil index tend to be less unequal. The correlation coefficient between spatial Theil Entropy and Gini coefficient is 0.5614 implying a strong positive association.

Regression models, moving average, and prediction maps

\section{Determinants of center and state liability}

The determinants of Center and State Liability for India staring from the pre-liberalization period when the debt crisis began are analyzed utilizing timeseries data (1980-81 to 2019-20). Four multiple regression models are run using JMP statistics software. The dependent and explanatory variables are listed in Table 1 and the size of the sample (N) is 40 .

Model 1 examines the relationship between total liability at center and states (TLC\&S) and lending rate (LR) as well as net FDI flows (N-FDIF) at the national scale. The regression coefficients shows a negative relationship between LR and TLC\&S. The coefficient suggests for every one percentage point increase in LR, the TLC\&S decreases by $2,765,352$ (Rupees Million) holding N-FDIF constant. The second regression coefficient shows a positive relationship between TLC\&S and N-FDIF and suggests that an increase of a million-dollar (US) net-FDI flow will increase TLC\&S to the extent of 2397.97 (Rupees Million). The UN-ESCAP (2021) reports that India will be the recipient of sizeable FDI flows in the information, communication and construction sectors although in the short-term these flows will decline. Such a positive FDI inflow entails an increase in total liability at center and state levels for an increase in productive expenditure. The resilience of the Indian economy and the thriving local digital ecosystem will continue to attract FDI inflows. All slope estimates are significant at a 5 percent significance level. The model shows a R-square of 0.883 which implies 88.3 percent of the variation in the dependent variable TLC\&S is due to variations in lending rate and net FDI flows.

Model 2 examines the relationship between total liability at center and states (TLC\&S), lending rate (LR), and trade balance (TB). Both LR and TB have negative regression coefficients. For every one million US dollar increase in India's TB, TLC\&S will decrease by 388.51 (Rupees Million). The explanatory 
(a)

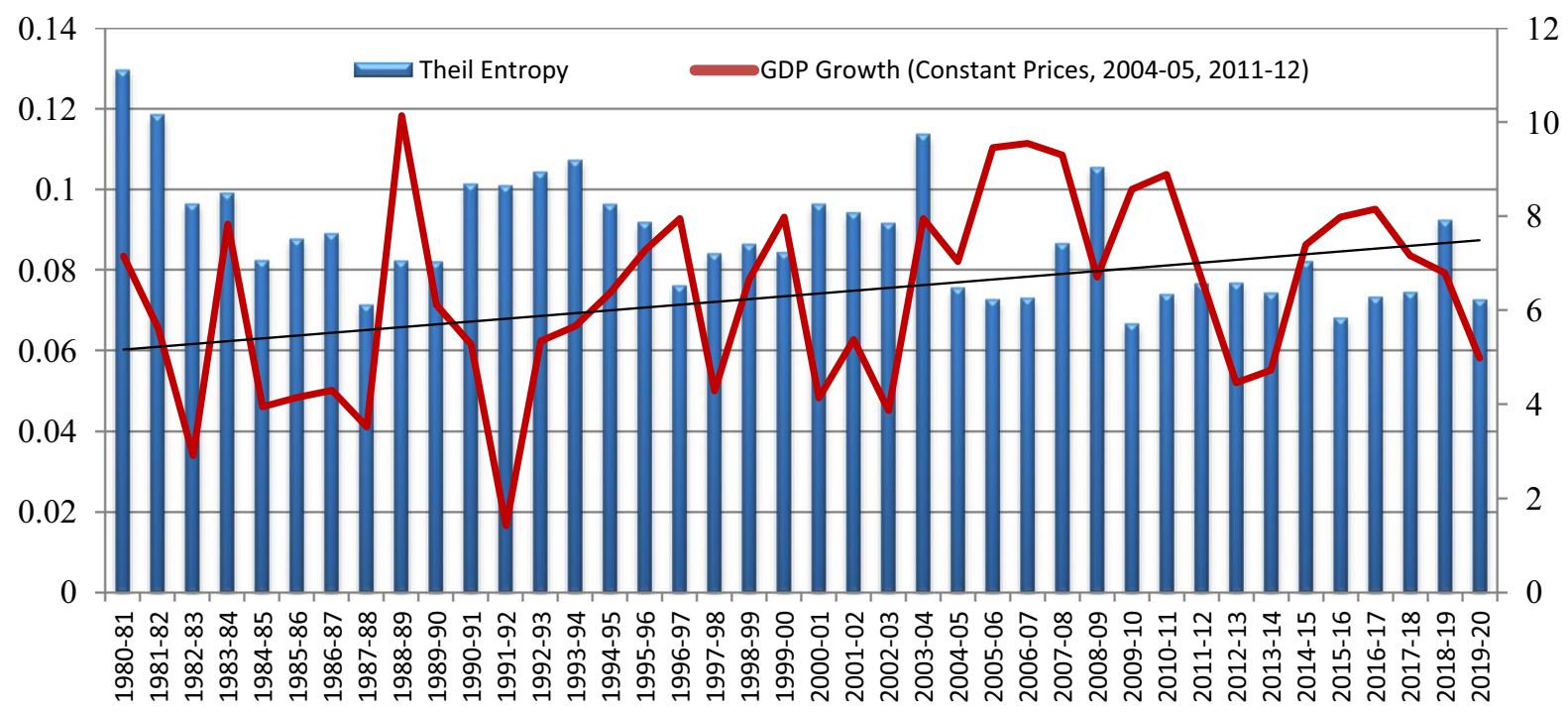

(b)

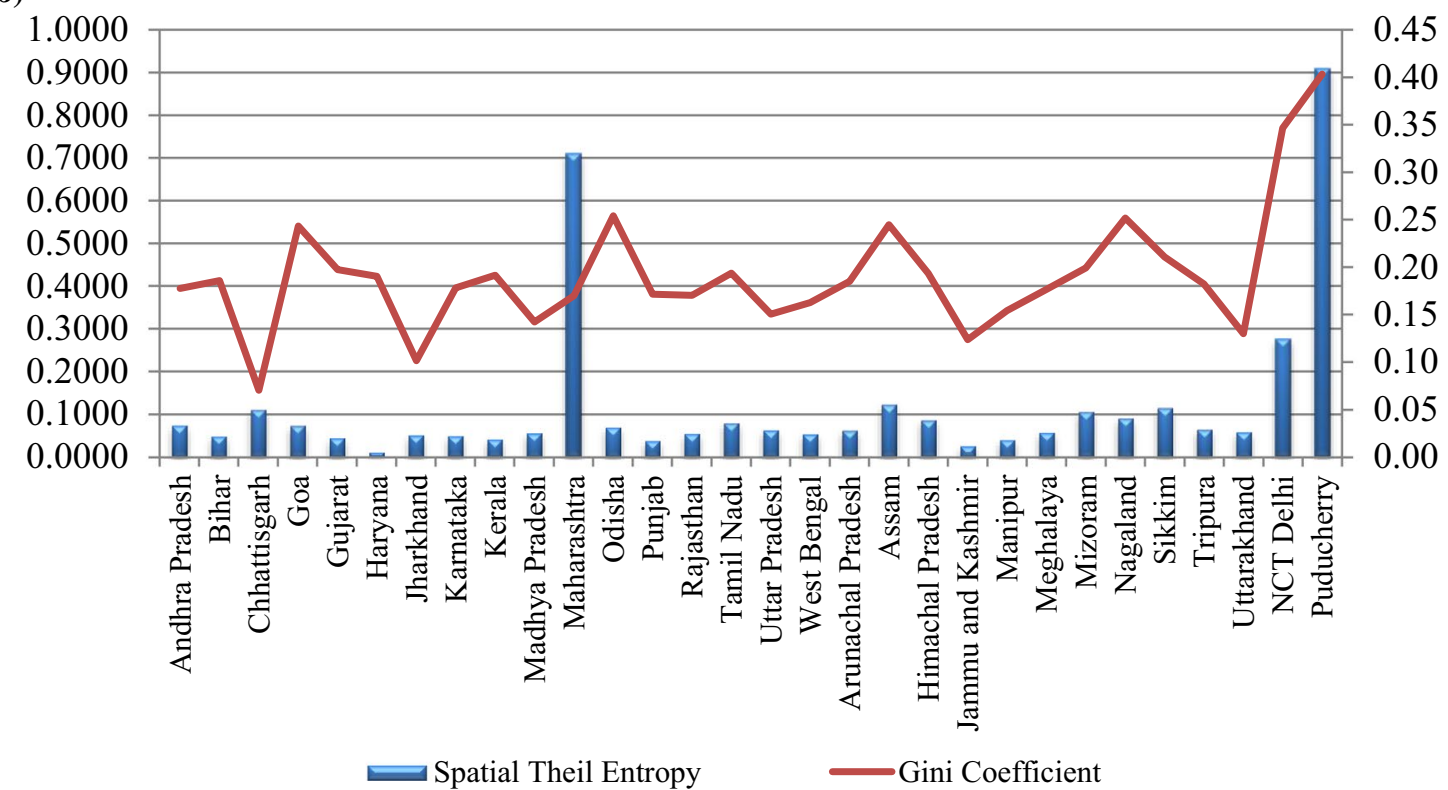

Fig. 7 a Theil entropy versus GDP rate of growth (Constant Prices, 2004-05, 2011-12) for Indian Economy: 1980-81 to 2019-20. b Spatial theil entropy versus gini coefficient for Indian Economy: 1980-81 to 2019-20. Source: State Finances (1981-2020), RBI

variables LR and TB are statistically significant and the model displays a high R-square of 78.2 percent. A positive trade balance is growth inducing which aids in decreasing total liability (TLC\&S), since it generates more financial resources for capital formation, productive investment in projects with higher rates of return, and lowering interest cost.

Model 3 examines the relationship between TLC\&S, LR, GDP growth, and TB. It can be hypothesized that higher growth leads to a decline in the total liability of the economy. LR and GDP growth 
Table 1 Variable definition

\begin{tabular}{|c|c|}
\hline Variable & Definition \\
\hline \multicolumn{2}{|l|}{ Dependent variable } \\
\hline $\begin{array}{l}\text { Total liability of center and states (TLC\&S) } \\
\text { (Rupees Million) }\end{array}$ & $\begin{array}{l}\text { TLC\&S is the sum of the external liabilities of the Centre and combined domestic } \\
\text { liabilities of Center and State (Rupees Million) }\end{array}$ \\
\hline \multicolumn{2}{|l|}{ Explanatory variable } \\
\hline Lending rate (LR) & $\begin{array}{l}\text { LR refers to either prime lending rate (PLR), or benchmark prime lending rate } \\
\text { (BPLR), base rate, or marginal cost of funds-based lending rate (MCLR) as the case } \\
\text { may be for the relevant year }\end{array}$ \\
\hline Gross domestic product (GDP) & $\begin{array}{l}\text { Annual GDP is defined as sum total of good and services produced in an economy } \\
\text { during fiscal year expressed in Rupees (Million) }\end{array}$ \\
\hline GDP growth $(\%)$ & $\begin{array}{l}\text { Annual GDP growth computes the performance of India's growth. This series is the } \\
\text { annual gross domestic product growth expressed in percentage terms }\end{array}$ \\
\hline Trade balance (TB) & It is the difference between India's annual exports and imports (US Million dollars) \\
\hline Foreign exchange reserves (FER) & $\begin{array}{l}\text { The foreign exchange reserves are the sum of gold, RTP, SDRs, and foreign currency } \\
\text { assets (US Million dollars) in India held annually }\end{array}$ \\
\hline Net-foreign direct investment flows (N-FDIF) & $\begin{array}{l}\text { It is computed as the difference between the inward and outward direct investment. } \\
\text { The inward foreign direct investment consists of investments by non-resident } \\
\text { investors including reinvested earnings, intra-company loans, net of repatriation of } \\
\text { capital, and repayment of loans. Likewise, outward investment comprises of equity, } \\
\text { loan, and guarantees issued in (US million \$) }\end{array}$ \\
\hline
\end{tabular}

Source Handbook of Statistics on Indian Economy (2019-20) Reserve Bank of India, Mumbai

shows a negative relationship with TLC\&S. A one percentage point increase in GDP growth generates a decline in TLC\&S by 3,396,027 (Rupees Million). Thus, increase in GDP growth spurs a decline in total liability. LR depicts a negative relationship and TB a positive relationship with TLC\&S. All three predictors and the model are statistically significant with $\mathrm{P}$ values less than 0.05 . The R-square for the model is high with 84.2 percent.

Model 4 examines the relationship between TLC\&S and three independent variables: GDP, TB, and FER. GDP, TB and foreign exchange reserves (FER) depicts a positive cause and effect relationship with TLC\&S. For example, the coefficient for FER implies for every one million dollars increase in FER it generates an increase in total liability (TLC\&S) by 83.99 (Rupees Million). Positive and healthy foreign exchange reserves can nudge the economy to incur higher debt levels to elevate productive capital for investing in projects with higher rates of return. The model and all three predictors are statistically significant and the model exhibits a R-square of 98.0 percent. The root means squared error (RMSE) computes the standard error of the residuals. It measures the magnitude of variation in the residuals around the fitted line. Using this criteria model 4 has the lowest standard error or RMSE and hence is the better model amongst the four.

Further, inference in multiple regression models can be examined by interpreting the F-test and by building confidence intervals for the estimates. First, the F-test utilizes the F-statistic to test the collective effects of all the explanatory variables on the dependent variable. The null hypothesis of the F-test posits that the data are a sample from a population in which all of the slopes in the regression are equal to 0 . The alternate hypothesis tests if the data are a sample from population in which all of the slopes of the regression are not equal to 0 . The F-statistic is a ratio of the sample variance of the fitted values to the variance of the residuals. Since the associated $\mathrm{P}$ values for F-ratio in each of the four models are less than 0.0001 the null hypothesis is rejected (Table 2). This implies the explanatory variables in each model together explains statistically significant variation in total liability (TLC\&S). Second, a 95\% confidence interval is constructed for selected variables from the four models. The $95 \%$ confidence interval for lending rate and Net FDI flows for model 1 are [ -5065334.05 , - 465,369.94] and [1868.23, 2927.71], trade balance in model 2 is [- 11316.45, - 239.72], GDP growth in model 3 is [- 5257795.0848, - 1,534,258.91] 
Table 2 Determinants of center and state liability in India: 1980-81 to 2019-20

\begin{tabular}{|c|c|c|c|c|c|c|}
\hline & Estimate & Standard error & t ratio & $\mathrm{p}$ value & F-ratio/F-statistic & RMSE \\
\hline Model 1/independent variable & & & & $<0.0001 *$ & 140.2039 & $14,076,689$ \\
\hline Intercept & $45,483,416$ & $17,255,350$ & 2.64 & $0.0122 *$ & $<0.0001 *$ & \\
\hline Lending rate & $(-) 2,765,352$ & $1,135,233$ & -2.44 & $0.0198 *$ & & \\
\hline Net FDI flows & 2397.97 & 261.4705 & 9.17 & $<0.0001^{*}$ & & \\
\hline \multicolumn{7}{|l|}{$\mathrm{R}$ square $=0.88$} \\
\hline Model 2 /independent variable & & & & $<0.0001^{*}$ & 66.6573 & $19,216,903$ \\
\hline Intercept & $70,843,390$ & $23,820,252$ & 2.97 & $0.0051 *$ & $<0.0001^{*}$ & \\
\hline Lending rate & $(-) 4,359,145$ & $1,558,526$ & -2.80 & $0.0081 *$ & & \\
\hline Trade Balance & $(-) 388.51$ & 73.44284 & -5.29 & $<0.0001^{*}$ & & \\
\hline \multicolumn{7}{|l|}{$\mathrm{R}$ square $=0.78$} \\
\hline Model 3/independent variable & & & & $<0.0001^{*}$ & 64.2341 & $16,583,419$ \\
\hline Intercept & $99,990,063$ & $22,014,222$ & 4.54 & $<0.0001^{*}$ & $<0.0001^{*}$ & \\
\hline Lending rate & $(-) 4,983,835$ & $1,355,506$ & -3.68 & $0.0008 *$ & & \\
\hline GDP growth $(\%)$ & $(-) 3,396,027$ & $918,031.6$ & -3.70 & $0.0007 *$ & & \\
\hline Trade balance & $(-) 361.37$ & 63.80156 & -5.66 & $<0.0001^{*}$ & & \\
\hline \multicolumn{7}{|l|}{$\mathrm{R}$ square $=0.84$} \\
\hline Model 4/independent variable & & & & $<0.0001^{*}$ & 1438.802 & $3,801,409$ \\
\hline Intercept & $-7,531,348$ & $896,811.6$ & -8.40 & $0.0001 *$ & $<0.0001^{*}$ & \\
\hline GDP & 0.7988 & 0.043443 & 18.39 & $0.0001 *$ & & \\
\hline Trade balance & 114.40 & 23.15997 & 4.94 & $0.0001 *$ & & \\
\hline $\begin{array}{l}\text { Foreign exchange reserves } \\
\text { R-square }=0.98\end{array}$ & 83.99 & 12.68369 & 6.62 & $<0.0001^{*}$ & & \\
\hline
\end{tabular}

Source Regression Output from JMP Statistics Software

$* \mathrm{p}<0.05$ level of significance, $\mathrm{N}=40$

and GDP and FER in model 4 are [0.710703396, $0.886908204]$ and $[58.27,109.71]$. It is observed that $\mathrm{P}$ values for each of these explanatory variables are less than 0.05 and the value 0 is not in the $95 \%$ confidence interval. This implies that $95 \%$ of the time this confidence interval is computed it is going to overlap with the true parameter value of the parameter being estimated. Thus, the sample data is a good representation of the population and the estimates are a reliable measure of the unknown population parameter.

\section{Moving average and state lag regression}

The moving average method computes the average of the most recent $k$ data values in the time series as the forecast for the subsequent period. Utilizing the state liability data for $1980-81$ to $2019-20$ a threeyear moving average is computed. The 2019-20 timeseries data is withheld and the state liability data for 2016-17, 2017-18, and 2018-19 compute the values for 2019-20. Then the actual and computed are compared and the Pearson correlation coefficient value is determined to be equal to 0.997 (Fig. 8a).

$$
\begin{aligned}
\left(\text { StateLiability }_{t}=\right. & f\left[\left(\text { StateLiability }_{t-1},(\text { StateLiability })_{t-2},\right.\right. \\
& \left.\times(\text { StateLiability })_{t-3}\right]
\end{aligned}
$$

The state lag regression model hypothesizes the state liability of a current year $(t)$ is a function of the state liability during the previous period $(t-1)$ and the gross state domestic product for $(t-1)$.

$(\text { State Liability })_{t}=\beta_{0}+\beta_{1}(\text { State Liability })_{t-1}+\beta_{2} G S D P_{t-1}+\varepsilon$

The state lag regression models are run utilizing the data for $1980-81$ to $2018-19$ to estimate the regression equation and then predict the forecast value for 2019-20 for each state. The actual debt (2019-20) and the forecasted debt (2019-20) are compared for each state for measuring association 
(a)

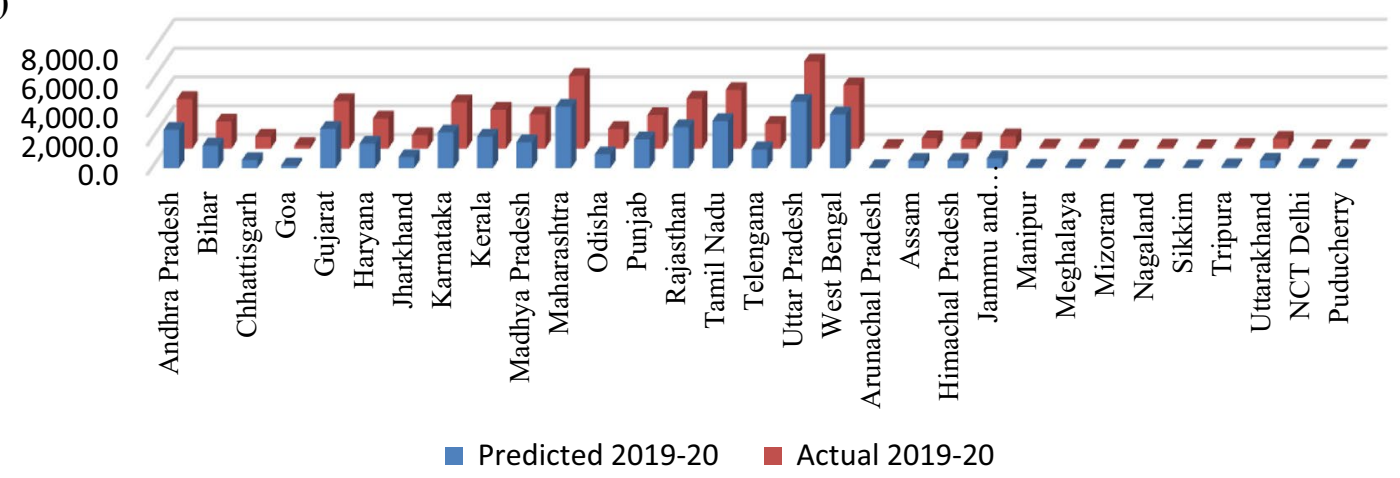

(b)

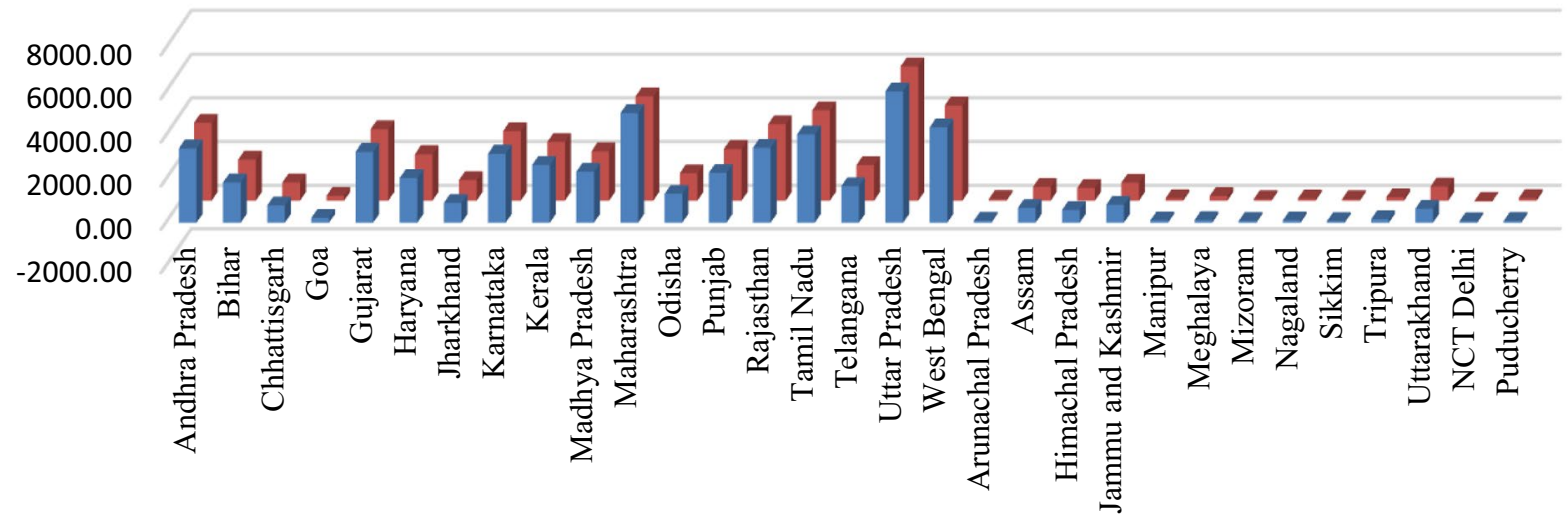

n Actual 2019-20 a Predicted 2019-20

Fig. 8 a Three year moving average forecast of state liability India (Rupees Billion): 2019-20. Source JMP Software Output, State Finances (2016-17 to 2018-19), RBI. b State lag

(Fig. 8b). The Pearson correlation coefficient has a value of 0.99 implying the actual and predicted are very close. Subsequently, five measures of error deviation are computed: mean deviation (MD), mean absolute deviation (MAD), mean percentage error (MPE), mean absolute percentage error (MAPE), and root mean squared error (RMSE) in Table 3. The state lag regression model depicts a higher error deviation for MD and MAPE compared to a three-year moving average. Also, the three-year moving average has regression forecast, Indian states: actual versus predicted state liability, 2019-20 (Rupees Billion). Source JMP Software Output, State Finances (1980-81 to 2018-19), RBI

a higher error deviation for MAD, MPE, and RMSE relative to the state regression model.

\section{State liability prediction maps}

Figures 9a-c depicts the predicted state debt levels (Rupees Billion) for Indian states utilizing the state lag regression model for the periods 2020-21, 2022-23, and 2024-25. Absolute debt levels will be high during both 2020-21 and 2022-23 in a majority of developed (Gujarat, Maharashtra, Andhra
Table 3 Measures of error structure

Source Author computation

\begin{tabular}{llllll}
\hline Statistical model & MD & MAD & MPE & MAPE & RMSE \\
\hline Three year moving average & 1414.98 & 338.131 & $564,103,190.34$ & $92,169.06$ & 45.3 \\
State lag regression model & 1696.28 & 47.5739 & $552,037,754.5$ & $166,575.55$ & 13.88 \\
\hline
\end{tabular}


(a)
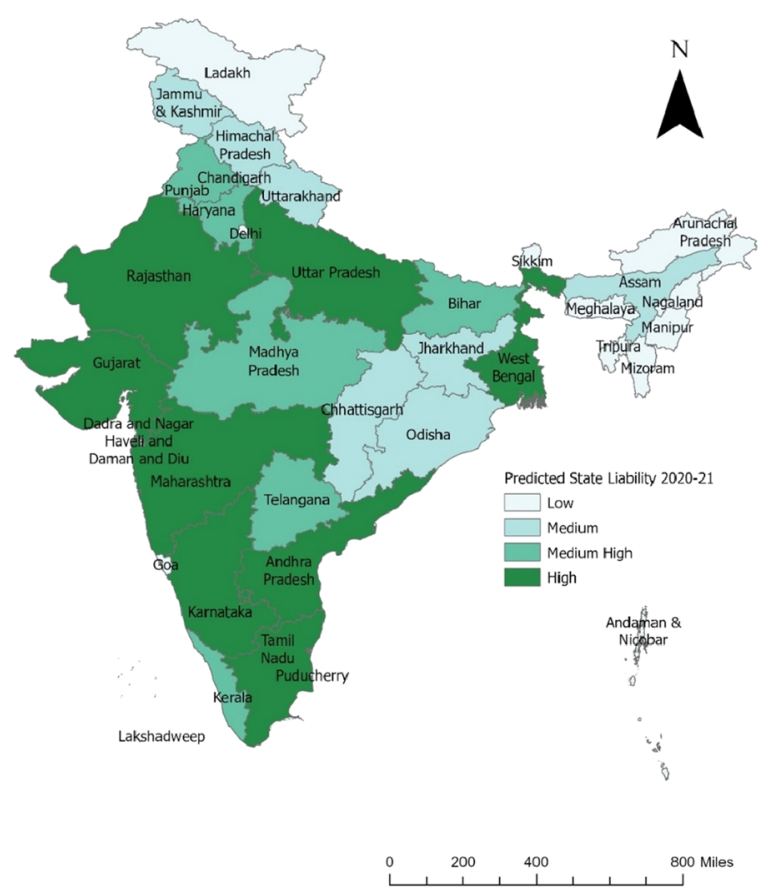

(c)

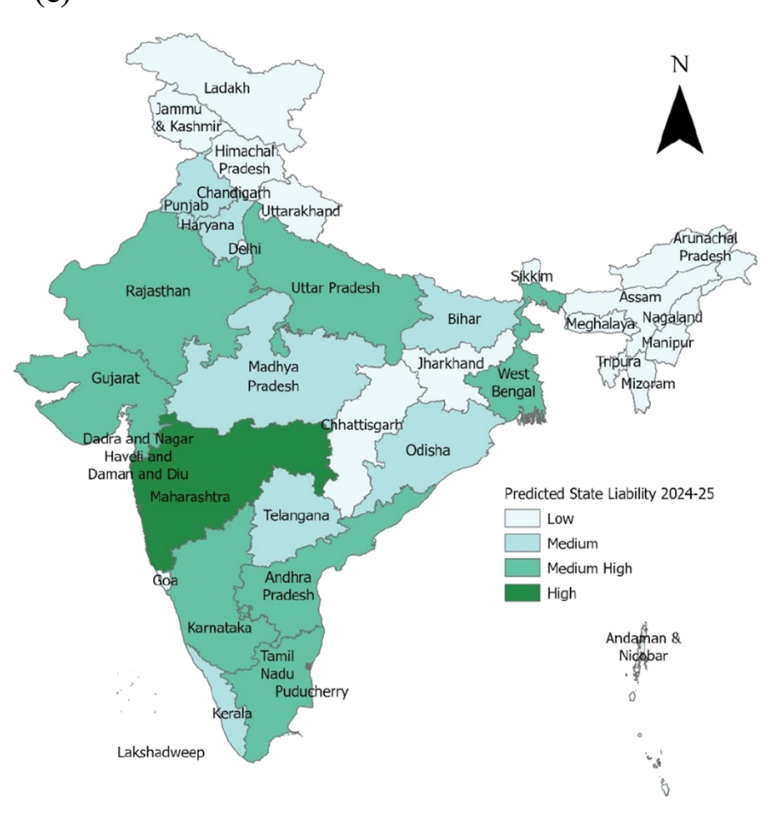

$\stackrel{200}{0}, 400, \quad+800$ Miles

Fig. 9 a Predicted state liability for Indian economy (Rupees Billion): 2020-21. b Predicted state liability for Indian economy (Rupees Billion): 2022-23. c Predicted state liability (b)

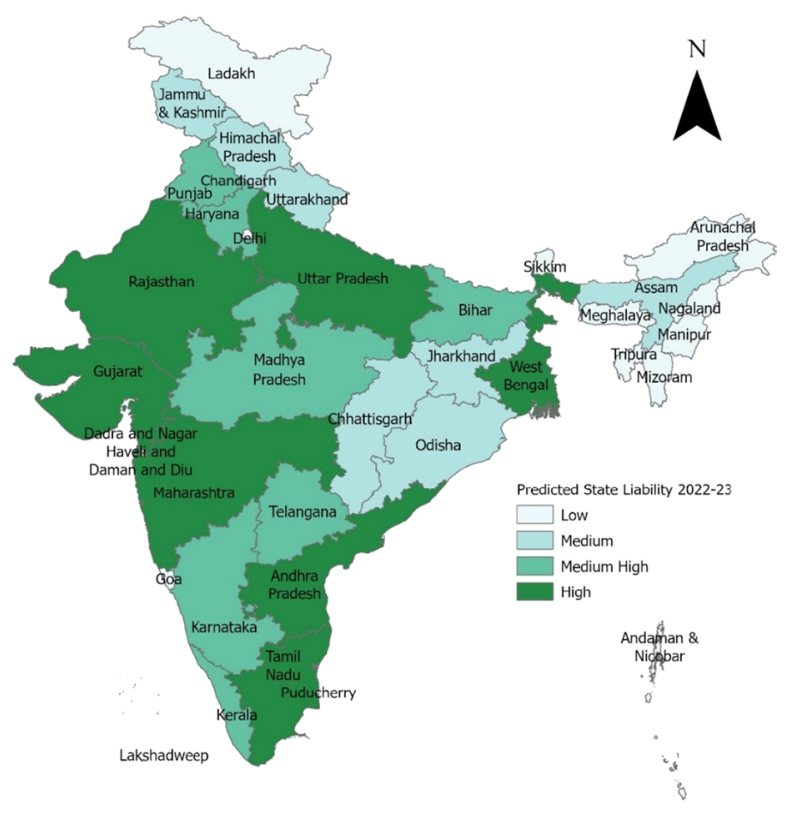


Pradesh, and Tamil Nadu) and less developed states (Rajasthan, Uttar Pradesh, Bihar, Sikkim, and West Bengal). By 2024-25 there will be some relief but the pattern will be similar. Maharashtra will have the highest debt level. The pattern shows both rich states and poor states will have high debt with the caveat that rich states will pay for service costs and plan expenditure. In comparison, the poor states will pay for huge debt servicing costs and non-plan expenditure. In addition, the current health crisis and increased number of Covid-19 related fatalities will only exacerbate and set back the Indian economy due to mass unemployment of migrant workers and debilitating performance of non-performing assets in the banking industry.

\section{Conclusion}

The global financial meltdown has surged public debt and the pandemic has exacerbated every nation's fiscal health adversely. Reinhart and Rogoff's (2010) study hypothesized if debt levels were higher than 90 percent then the growth rate would taper off sharply. This stylized fact has been criticized by economic geographers since local context matters, and one size fits all approach does not address the problem. Thus, this limitation motivated a spatial analysis of public debt providing insights for policy implications.

This study examines space-time patterns of public debt ratio and its determinants in India. Five observations can be made. First, visualization of an aggregate pattern of debt ratio during 1980-81 to 2019-20 depicts three clusters. High debt states are located in Jammu and Kashmir, Bihar, Sikkim, and most of the Northeastern states. Medium debt states comprise most of the western, northwestern, and central states in India. The low debt states are located in the industrial, high technology, and agricultural states in western and southern India namely Maharashtra, Karnataka, Tamil Nadu, and Haryana, which forms a horizontal (H) pattern.

Second, Gini and standard deviation measures show that debt ratio was relatively high during the 1990s relative to the 1980s and 2000s, followed by a marginal decline during 2010-2020. Likewise, the high entropy indicates debt ratio was uneven over time. Moreover, a low entropy for cross-sectional data implies the ratio was distributed relatively evenly over geographical space.

Third, four multiple regression models were estimated utilizing time-series data to explain the determinants of total liability of centers and states (TLC\&S). Model 1 shows a negative relationship between lending rate (LR) and TLC\&S. Regression coefficients show a positive relationship between net FDI flows (N-FDIF) and TLC\&S. Model 2 estimates the relationship between TLC\&S and LR as well as the trade balance (TB). It indicated a negative relationship with both explanatory variables. Model 3 estimates the relationship among TLC\&S and LR, GDP growth, and TB. All three predictors show a positive cause and effect relationship. Model 4 estimated the relationship between TLC\&S and three independent variables: GDP, TB and foreign exchange reserve (FER). All three explanatory variables show a positive relationship with TLC\&S. Further, an F-test and confidence interval of the estimates suggest the following inference. The sample data is a good representation of the population and the estimates are a reliable measure of the unknown population parameter.

Fourth, moving average and state lag regression models estimated the state liability for 2019-20 using three prior values and historical data. The actual and computed values were compared and the correlation coefficient values were 0.997 and 0.99 implying strong association between actual (2019-20) and predicted state liability (2019-20).

Fifth, the state liability (Rupees Billion) prediction maps for 2020-21, 2022-23, and 2024-25 show that during 2020-21 most of the lagging and developed states have high debt levels. Lagging states will pay for high servicing costs and non-plan expenditure and developed states will pay for servicing costs and plan expenditure. During 2022-23 the spatial debt pattern will be similar. Subsequently, during 2024-25 Maharashtra will be the only state in the high debt category and other states will relatively improve their debt position.

Thus, the lessons drawn from the statistical analysis of the determinants of total liability at center and state levels are: (1) increase in lending rate decreases the incentive for increasing debt at the center and state government levels, (2) positive trade balance is growth inducing which aids in decreasing total liability (TLC\&S), since it generates more financial 
resources for capital formation, productive investment in projects with higher rates of return, and lowering interest cost, (3) a positive increase in GDP raises the capacity of the government to increase total liability for enhancing productive expenditure in sectors with highest rate of return, (4) external sources of financial resources (trade balance, foreign exchange reserves and net foreign direct investment) generates an increase in total liability. It must be utilized prudently for investment in those sectors that stimulates the highest rate of return and utilizes financial resources to reduce interest cost burden.

Debt geography is a new area of research globally as well as in India. Future research endeavors will examine the following questions: (1) What are the geographical determinants of public debt in developing countries such as India? (2) Is the relationship between debt and regional development influenced by the spatial distribution of inequality? (3) Does the regional debt distribution of Indian states show characteristics of persistence, mobility, polarization, and stratification? Also, (4) would the relationship between public debt and regional growth be influenced under the assumption of spatial dependence utilizing a spatial statistics framework?

Acknowledgements A draft version of this paper was presented at the Department of Geography, Panjab University, Chandigarh (2016), Delhi School of Economics (2017), Allahabad University (2018), Applied Geography Conference, (Kent, 2018), and 12th World Congress of Regional Science Association International, Goa (2018). I thank the scholars and faculty who attended and made useful comments. I also wish to thank anonymous reviewers for their valuable comments.

\section{Appendix 1}

\section{Determinants of public debt: analytical framework}

A budget deficit is defined as the difference between government expenditure and income and tax receipts. It is the sum of spending and interest payment on debt less taxes net of transfers. Blanchard (2009) provides an analytical framework to understand the growth and evolution of debt. The budget deficit can be expressed as $\left(D_{t}=B_{t}-B_{t-1}\right)$ :
$D_{t}=s B_{t-1}+G_{t}-X_{t}$

$D_{t}$ is deficit in year $t$.

$B_{t-1}$ is government debt at the end of year $t-1$ and thus, $s B_{t-1}$ is the product of real interest rate and debt in year $t$.

$s$ is the real interest rate which will be assumed to be constant.

$G_{t}$ is government spending on goods and services during year $t$.

$X_{t}$ are taxes subtracting transfers during year $t$.

In Eq. (4) the first term on the right-hand side is the interest payment and the second term is the primary deficit. Substituting $D_{t}$ in Eq. 4 and rearranging terms the equation can be expressed in terms of $B_{t}$.

$B_{t}=(1+s) B_{t-1}+G_{t}-X_{t}$

The second equation implies debt in year $t$ is the sum of two terms: debt at the end of year $t-1$ multiplied by $(1+s)$ and added to the primary deficit $\left(G_{t}-X_{t}\right)$ at the end of year $t$. Equation (6) shows the relationship between output growth assumed to be constant and measured by $\left(Z_{t}\right)$ and the rate of growth of output measured by $(h)$.

$\frac{B_{t}}{Z_{t}}-\frac{B_{t-1}}{Z_{t-1}}=(s-h) \frac{B_{t-1}}{Z_{t-1}}+\frac{G_{t}-X_{t}}{Z_{t}}$

The simple interpretation of Eq. (6) is that change in debt over time is a sum of two components. The first component is the difference between real interest rate and the growth rate multiplied by the initial debt ratio, and the second component is the primary deficit as a ratio of GDP. Equation (6) can provide a deeper understanding of the spatial and temporal evolution of deficit.

\section{References}

Bajpai, N., and Sachs, J.D. (1999). The state of government finance in India. Development Discussion Paper No. 719, Harvard Institute for International Development, Harvard University

Baskaran, T. (2012). Soft budget constraints and strategic interactions in subnational borrowings: Evidence from the German States, 1975-2005. Journal of Urban Economics, 71(1), 114-127.

Batty, M. (1974). Spatial entropy. Geographical Analysis, 8, $1-32$. 
Batty, M. (2010). Space, scale, and scaling in entropy maximizing. Geographical Analysis, 42, 395-421.

Bell, A., Johnston, R., \& Jones, K. (2015). Stylized facts or situated messiness? The diverse effects of increasing debt on national economic growth. Journal of Economic Geography, 15, 449-472.

Blanchard, O. (2009). Macroeconomics (5th ed.). Pearson Prentice Hall.

Borck, R., Fossen, F. M., Freier, R., \& Martin, T. (2015). Race to the debt trap: Spatial econometric evidence on debt in German municipalities. Regional Science and Urban Economics, 53, 20-37.

Chelliah, R. J. (1999). Towards sustainable growth: Essays on fiscal and financial sector reforms in India. Oxford India Paperbacks Oxford University Press.

Christopher, B. (2015). The limits to financialization. Dialogues in Human Geography, 5(2), 183-200.

Foremny, D. (2014). Subnational deficits in European countries: The impact of fiscal rules and tax autonomy. European Journal of Political Economy, 34, 86-110.

Herndon, T., Ash, M., \& Pollin, R. (2014). Does high public debt consistently stifle economic growth? A critique of Reinhart and Rogoff. Cambridge Journal of Economics, 38, 257-279.

Kapila, U. (Ed.). (2009). Indian economy since independence: New revised (20th ed.). Academic Foundation.

Kaur, B., \& Mukherjee, A. (2012). Threshold level of debt and public debt sustainability: The Indian experience. Reserve Bank of India, Occasional Papers, 33(1\&2), 1-37.

Kaur, B., Mukherjee, A., \& Ekka, A. P. (2018). Debt sustainability of states in India: An assessment. Indian Economic Review, 53, 93-129.

Kaur, B., Mukherjee, A., Kumar, N., \& Ekka, A. P. (2014). Debt sustainability at the state level in India. WPS (DEPR): 07/2014 RBI working paper series. Department of Economic and Policy Research, Reserve Bank of India.

Kishore, A., \& Prasad, A. (2007). Indian subnational finances: recent performance. IMF working paper, WP/07/205. International Monetary Fund.

Lu, M. (2020). Debt-to-GDP continues to rise around the world, Visual Capitalist. Retrieved 15 December, 2020, from www.visualcapitalist.com

Makin, A. J., \& Arora, R. (2012). Fiscal sustainability in India at state level. Public Finance and Management, 12(40), 350-367.

Martin, R., \& Pollard, J. (Eds.). (2017). Handbook on the geographies of money and finance. Edward Elgar Publishing.

Misra, S. K., \& Puri, V. K. (1996). Indian economy: Its development experience. Himalaya Publishing House.

Mitze, T., \& Matz, F. (2015). Public debt and growth in German federal states: What can Europe learn? Journal of Policy Modeling, 37, 208-228.

Molina-Parra, A., \& Martinez-Lopez, D. (2018). Do federal deficits motivate regional fiscal (im)balances? Evidence for the Spanish case. Journal of Regional Science, 58(1), 224-258.

Ostry, J. D., Ghosh, A. R., Kim, J. I., \& Qureshi, M. S. (2010). Fiscal space. IMF staff position note, SPN/10/11. International Monetary Fund.
Patil, V.K. (2016). State's government debt stands at more than Rs. 1 Lakh crore. The Hindu, March 24th, 2016. Retrieved 20 January, 2017

Raghavan, T.C.A. (2019). Center's debt-to-GDP falls, state's rises, The Hindu. Retrieved 22 January, 2019

Rajan, R. (2019). The third pillar: How markets and the state leave the community behind. Harper Collins Publishers.

Rao, M. G., \& Jena, P. R. (2009). Recent trends in state finances. In M. G. Rao \& A. Shah (Eds.), State's fiscal management and regional equity: An overview. Oxford University Press.

Reinhart, C. M., \& Rogoff, K. S. (2010). Growth in a time of debt. American Economic Review, 100, 573-578.

Reserve Bank of India (2009). State of finances: a study of budgets of 2008-09. Department of Economic and Policy Research, 6th Floor, Reserve Bank of India, Government of India, Mumbai

Reserve Bank of India. (2014). Handbook of statistics of Indian states. Reserve Bank of India, Government of India.

Reserve Bank of India (2017). State of finances: a study of budgets of 2016-17. Department of Economic and Policy Research, 6th Floor, Reserve Bank of India, Government of India, Mumbai

Roomero, A. A., \& Burkley, M. L. (2011). Debt overhang in the eurozone: A spatial panel analysis. The Review of Regional Studies, 41, 49-63.

Salve, P. (2015). Maharashtra most indebted, Tamil Nadu gathering debt fastest. Retrieved October 31, 2015, from http://www.indiaspend.com/cover-story/maharashtramost-indebted-tamil-nadu-gathering-debt-fastest-73343

Stiglitz, J. E. (2016). The Euro: How a common currency threatens the future of Europe. W.W. Norton and Company.

Thakur, S. K. (2020). Public debt and regional inequality in India: Spatial planning implications. In R. R. Thakur, A. K. Dutt, S. K. Thakur, \& G. Pomeroy (Eds.), Urban and regional planning and development: 20th century forms and 21 st century transformations (pp. 407-430). Springer.

The Economist (2017). Left behind: How to help places hurt by globalization, The Economist, October 21st-27th, London

Theil, H. (1967). Economics and information theory. NorthHolland Publishing Company.

UN-ESCAP (2021) Foreign direct investment trends and outlook in Asia and the Pacific, Asia-Pacific Trade and Investment Trends 2020/2021, United Nations: Bangkok

Wilson, A. G. (2010). Entropy in urban and regional modeling: Retrospect and prospect. Geographical Analysis, 42, 364-394.

World Bank. (2021). Global economic prospects. International Bank for Reconstruction and Development.

Publisher's Note Springer Nature remains neutral with regard to jurisdictional claims in published maps and institutional affiliations. 